Prepared in cooperation with Nevada Bureau of Mines and Geology; Arizona Geological Survey; University of Nevada, Las Vegas, Department of Geoscience; University of Oklahoma School of Geosciences; and National Park Service

\title{
Surficial Geologic Map of the Spirit Mountain SE and part of the Spirit Mountain NE 7.5' Quadrangles, Nevada and Arizona
}

By P. Kyle House, Ryan S. Crow, Philip A. Pearthree, Amy L. Brock-Hon, Jonathan Schwing, Jacob 0. Thacker, and Brian F. Gootee

Pamphlet to accompany

Scientific Investigations Map 3448

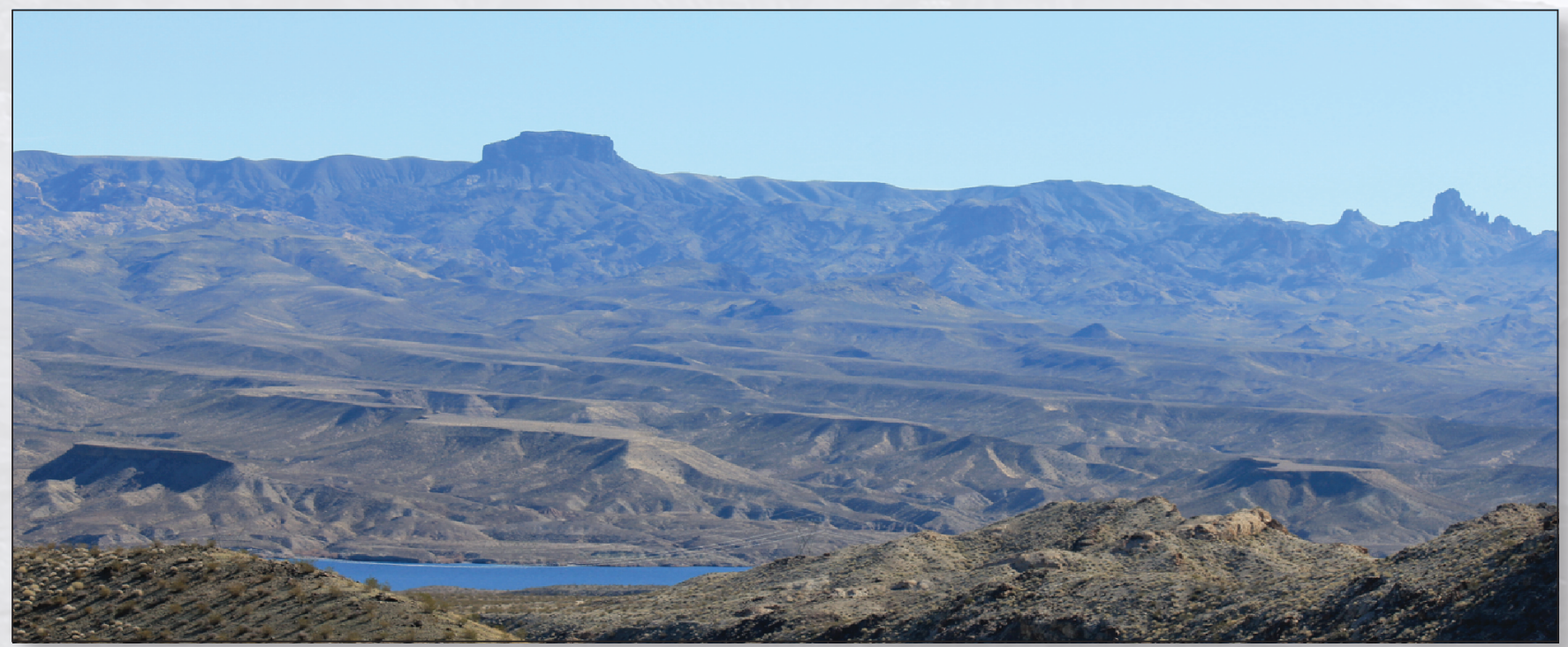

View to the east-southeast across the central part of the map area. Prominent and high-standing surfaces are capped with massive petrocalcic soil horizons (unit QTbk). The prominent flat peak on the horizon is an important local landmark in the Black Mountains known as "The Princess."

U.S. Department of the Interior

U.S. Geological Survey 


\title{
U.S. Department of the Interior \\ DAVID BERNHARDT, Secretary
}

\author{
U.S. Geological Survey \\ James F. Reilly II, Director
}

U.S. Geological Survey, Reston, Virginia: 2020

For more information on the USGS —-the Federal source for science about the Earth, its natural and living resources, natural hazards, and the environment—visit https://www.usgs.gov or call 1-888-ASK-USGS

For an overview of USGS information products, including maps, imagery, and publications,

visit https://store.usgs.gov.

Any use of trade, firm, or product names is for descriptive purposes only and does not imply endorsement by the U.S. Government.

Although this information product, for the most part, is in the public domain, it also may contain copyrighted materials as noted in the text. Permission to reproduce copyrighted items must be secured from the copyright owner.

Suggested citation:

House P.K., Crow, R.S., Pearthree, P.A., Brock-Hon, A.L., Schwing, J., Thacker, J.O., and Gootee, B.F., 2020,

Surficial geologic map of the Spirit Mountain SE and part of the Spirit Mountain NE 7.5' quadrangles, Nevada

and Arizona: U.S. Geological Survey Scientific Investigations Map 3448, pamphlet 30 p., scale 1:24,000,

https://doi.org/10.3133/sim3448.

ISSN 2329-132X (online) 


\section{Contents}

Abstract

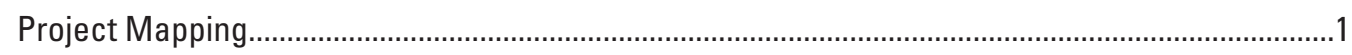

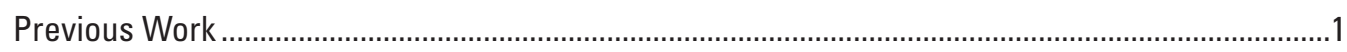

Overview of Neogene Extensional Tectonics and Structural Setting of Cottonwood Valley............3

Key Map Units Related to Arrival and Integration of the Colorado River...........................................

Late Miocene Pre-Integration Valley-Axis Deposits ................................................................

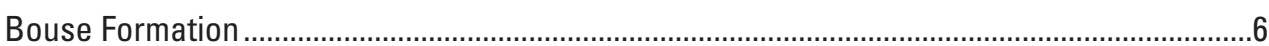

Bullhead Alluvium ...........................................................................................................

Chemehuevi Formation ......................................................................................................10

Piedmont Tributary Deposits ................................................................................................11

Summary of Late Neogene and Quaternary Evolution of Cottonwood Valley .................................14

Late Deposition of the Beds of Lost Cabin Wash ( 5.24 Ma)................................................14

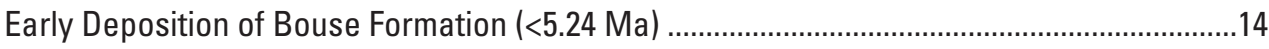

Late Deposition of Bullhead Alluvium ( 4 Ma)...............................................................14

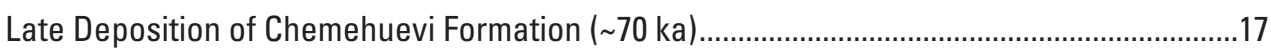

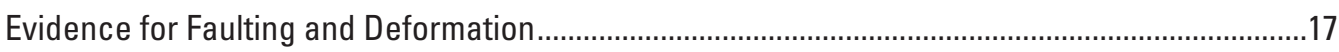

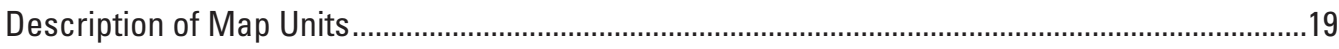

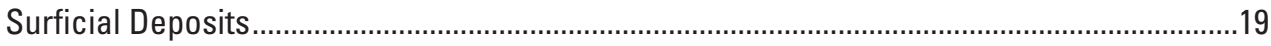

Miscellaneous Deposits .................................................................................................19

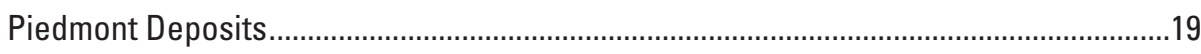

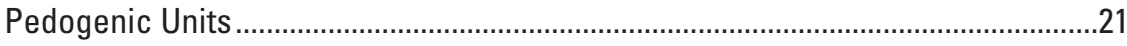

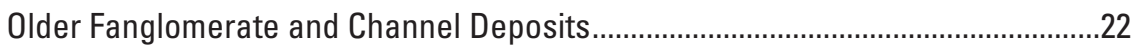

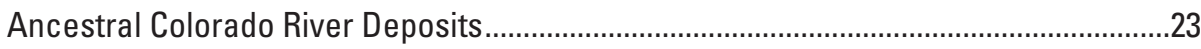

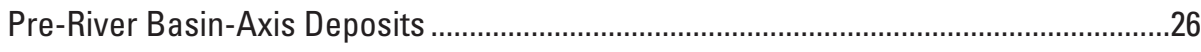

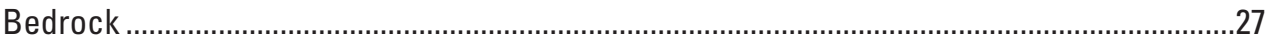

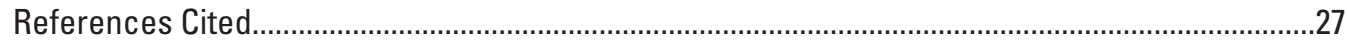

\section{Figures}

1. Location of map area. $A$, Regional setting of map area showing the approximate location of the Colorado River extensional corridor (CREC). $B$, Regional map showing map area and important physiographic and cultural features ............................2

2. The beds of Nellis Wash (unit Tnw) near Cactus Cove ...................................................

3. View to northwest across slot canyon formed in older paleochannel-fill conglomerate (unit Tfco), looking toward Lake Mohave and Eldorado Mountains, Nevada

4. A, Relatively thick sequence of beds of Lost Cabin Wash (unit Tlc) under fanglomerate of Black Mountains (unit Tfb) in the north-central part of the map area. $B$, The 5.37-Ma tephra layer in the upper part of the beds of Lost Cabin Wash in the informally named "highwall wash," overlain by younger and paleosol-bearing beds of Lost Cabin Wash that are cut by the fanglomerate of Black Mountains

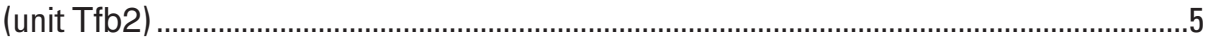

5. Key facies of the Bouse Formation in the map area .....................................................

6. A, Bouse Formation marl (unit Tbocm) sandwiched between fanglomerate of Black Mountains (unit Tfb, at top) and beds of Lost Cabin Wash (unit Tlc, bottom). $B$, Bouse Formation marl (unit Tbocm) overlain by bedded sand and mud of unit Tbos in the Lost Cabin Wash, Arizona, area .................................................................

7. Various views of the Bullhead Alluvium (unit Tcb) in Tyro Wash and nearby areas........8 
8. Boulder and cobble conglomerate (unit Tcbb) in the Bullhead Alluvium in Arizona part of map.

9. Lenticular beds of Colorado River sands (Bullhead Alluvium, unit Tcbs) interbedded with fanglomerate of Black Mountain (unit Tfb2) in upper Tyro Wash, Arizona.............10

10. Bullhead Alluvium (Tcb) paleochannel cut into Paleoproterozoic megacrystic granite near the Arizona shore of Lake Mohave............................................................10

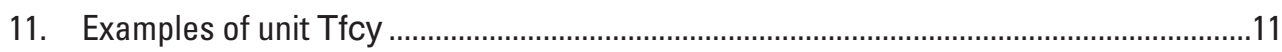

12. Chemehuevi Formation (unit Qch) in the map area .....................................................12

13. View to the east-southeast showing east-dipping beds of late Miocene fanglomerate of Newberry Mountains (unit Tfn) exposed in Granite Wash, Arizona

14. Massive stage VI Bkqm soil horizon on Pyramid mesa (unit QTbk1) that caps and includes mixed Colorado River and tributary gravel.....

15. Geologic map of the late Miocene and Pliocene deposits in the Spirit Mountain SE 7.5' part of the map area, showing direction of sediment movement from source .........15

16. Late Miocene to Pleistocene paleogeography. Four main stages in the geologic evolution of Cottonwood Valley, including the integration of Colorado River deposition

17. Stereonets of geometric and kinematic fault data collected in the map area.................18

18. Steeply dipping fault in unit Tfb1 in lower "highwall wash" near Cactus Cove 19 


\title{
Surficial Geologic Map of the Spirit Mountain SE and part of the Spirit Mountain NE 7.5' Quadrangles, Nevada and Arizona
}

\author{
By P. Kyle House ${ }^{1}$, Ryan S. Crow ${ }^{1}$, Philip A. Pearthree ${ }^{2}$, Amy L. Brock-Hon ${ }^{3}$, Jonathan Schwing ${ }^{4}$, Jacob 0. \\ Thacker ${ }^{1}$, and Brian F. Gootee ${ }^{2}$
}

\section{Abstract}

This geologic map includes a trove of stratigraphic and geomorphic information that chronicles the inception and evolution of the lower Colorado River. The map area is located near the south end of the Lake Mead National Recreation Area about $80 \mathrm{~km}$ (50 mi) downstream from Hoover Dam. It spans parts of northwestern Arizona and southern Nevada in the southern part of Cottonwood Valley. The map includes the Spirit Mountain SE 7.5' quadrangle and the southern part of the Spirit Mountain NE 7.5' quadrangle. The map area contains well-exposed Neogene and Quaternary strata and associated geomorphic features that record and are critical in dating the arrival of the Colorado River in the early Pliocene and the subsequent history of the river and its landscape through the Holocene. Cottonwood Valley is bounded on the west by the Newberry Mountains (Nevada) and on the east by the Black Mountains (Arizona) and includes part of Lake Mohave, a reservoir created by the completion of Davis Dam in 1951. This map does not include the geology of the reservoir floor and focuses only on surficial deposits.

\section{Project Mapping}

Field work began in the west half of the Spirit Mountain SE 7.5' quadrangle in 2002 with funding from the U.S. Geological Survey (USGS) STATEMAP program to the Nevada Bureau of Mines and Geology (NBMG; House) and with additional support from the Arizona Geological Survey (AZGS; Pearthree). A preliminary geologic map of the west half was released in 2005 by NBMG (House and others, 2005a). Additional field work towards a preliminary geologic map of the full quadrangle (House and others, 2008a) was made possible through the USGS National Cooperative Geologic Mapping Program (NCGMP) via STATEMAP and EDMAP funding in 2005-2007 to NBMG (House) and the University of Nevada, Las Vegas (Brock-Hon), respectively. Follow-on field work at various times in 2010-2018 added significantly to the preliminary maps and extended the mapping into the next quadrangle (Spirit Mountain NE) to the north. This map has been made possible with funding through the NCGMP (House and Crow), AZGS (Pearthree and Gootee), USGS/National Association for Geoscience Teachers Cooperative Field Training Program (Schwing), and National Science Foundation Graduate Research Internship Program (Thacker). Key discoveries about the history of the Colorado River based on findings in this area have been presented by House and others (2005b, 2008b), Pearthree and House (2014), Howard and others (2015), Crow and others (2018, 2019a), and Schwing (2019).

This geologic map covers a relatively rugged, mostly roadless area of Cottonwood Valley beginning about $11.5 \mathrm{~km}$ (7 mi) north of Bullhead City, Arizona, and Laughlin, Nevada. It includes the labyrinthine shoreline bluffs of Lake Mohave and all but the easternmost 1.6-km (1-mi) strip of the map is within the Lake Mead National Recreation Area (fig. 1B). Stratigraphic exposure in this deeply incised terrain is good, and stratigraphic relations are particularly complex in some parts of the map area. Collectively, much of the map area has been traversed on foot and mapped in the field by the authors. Mapping of the alluvialfan sequences relied more on interpretation of high-resolution aerial imagery and other remotely sensed data. Complex and intricate interbedded relations along the margins of important Colorado River units have not been mapped in detail owing to practical concerns of time and topography. This map does not include bedrock mapping.

\section{Previous Work}

${ }^{2}$ Arizona Geological Survey

${ }^{3}$ University of Nevada, Las Vegas

${ }^{4}$ University of Oklahoma
Previous geologic studies in this map area that describe aspects of the surficial deposits and Colorado River stratigraphy 

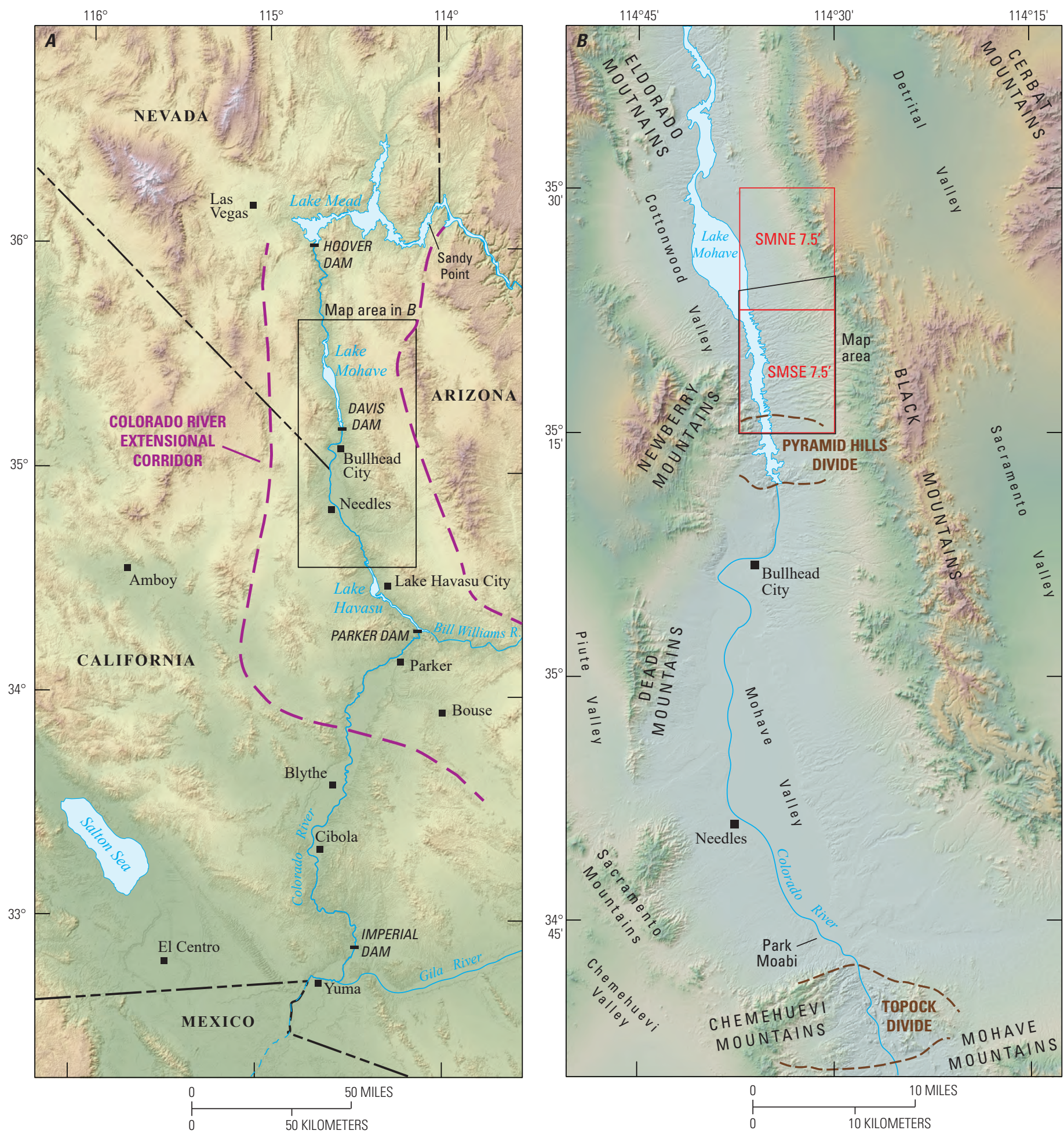

Figure 1. Location of map area. $A$, Regional setting of map area showing the approximate location of the Colorado River extensional corridor (CREC). $B$, Regional map showing map area and important physiographic and cultural features. The map area contains all of the Spirit Mountain SE 7.5' quadrangle (SMSE) and a relatively small part of the Spirit Mountain NE 7.5' quadrangle (SMNE). Maps modified from Pearthree and House (2014) and Howard and others (2019). Approximate CREC boundary modified from Spencer and others (2018).

are limited to those by Newberry (1861), Lee (1908), Longwell (1963), and Metzger and Loeltz (1973) and by previous publications and preliminary geologic maps by authors listed in foregoing sections. Detailed discussions of the middle to late Miocene structural history and stratigraphy can be found (for example) in Faulds (1995), Faulds and others (2000, 2001), and Langenheim and others (2010). A thorough discussion of the history of middle to late Miocene drainage development in areas immediately upstream of Cottonwood Valley is found in Faulds and others (2016). The preliminary geologic map of the 
Davis Dam 7.5' quadrangle (Faulds and others, 2000, 2004) and related interpretations of preliminary versions of this map presented in House and others (2005b, 2008b) first described evidence for hydrologic integration of Cottonwood and Mohave Valleys. Those studies and that of Pearthree and House (2014) document and describe the stratigraphic suite of basin fill, tributary alluvial fans, and Colorado River deposits that record the abrupt transition from dry, internally drained valleys to the basin of a single large lake and then to part of the continuous course of the early, sediment-charged Colorado River. The multi-year development of this geologic map was essential in the development of those interpretations.

\section{Overview of Neogene Extensional Tectonics and Structural Setting of Cottonwood Valley}

This map area is in Cottonwood Valley, the northernmost in a string of alluvial valleys along the Colorado River corridor downstream from Hoover Dam (fig. 1A). Most of these valleys are half-graben structural basins formed by moderate to intense extensional tectonics during the middle to late Miocene (for example, Faulds, 1995; Faulds and others, 2001; Langenheim and others, 2010). The basins are principal features of the Colorado River extensional corridor (CREC), a 70- to 100-kmwide zone of moderate to extreme crustal extension that spans the Colorado River valley roughly from Las Vegas, Nevada, to north of Blythe, California, and then east to the vicinity of Phoenix, Arizona (fig. 1A; Faulds and others, 2001; Howard and John, 1987; Spencer and others, 2018).

Cottonwood Valley occupies a structural basin in the northern Colorado River extensional corridor (NCREC; Faulds and others, 2001), a relatively narrow north-south-oriented tract of the CREC. Overall, this region has been the locus of significant tectonic activity since at least the Mesozoic, but the Neogene activity was critical in creating the geologic and topographic conditions related to the development of the lower Colorado River - the primary focus of this map.

The structural basin underlying Cottonwood Valley includes a series of relatively small, imbricate half-graben basins formed by a set of steeply west dipping blocks bounded by east-dipping normal faults (Faulds, 1995). Basin-filling deposits include volcanic and volcaniclastic rocks, rock avalanche deposits, and fanglomerate. Dated synextensional strata indicate that most of the crustal extension in the vicinity of the map area occurred 15.8-11.3 Ma, and extensional, detachmentfault-related tectonics largely ceased by $\sim 9$ Ma within the NCERC (Faulds and others, 2001).

Cottonwood basin formed in the hanging wall of the Dupont Mountain Fault, one of three major normal faults active during the Miocene in this area (Faulds, 1995). The Dupont Mountain Fault is probably the northward continuation of the Newberry detachment fault, a major, gently east dipping fault that accommodates the separation of two distinct lithologic domains in Cottonwood and Mohave Valleys: predominantly 17- and 15-Ma plutonic rocks of mostly granitic composition on the upthrown block (Newberry Mountains) and 20-15 Ma volcanic and sedimentary rocks resting on Paleoproterozoic granites on the downthrown block (Black Mountains). Ultimately, the tectonic history is much more complicated than offset along a single fault, but the net separation of these distinctly different rock types onto opposing sides of the basin plays a key role in unraveling the late Neogene history of the valley, particularly the arrival and evolution of the Colorado River.

Cottonwood Valley is separated at its south end from Mohave Valley by an east-trending bedrock high (informally named "Pyramid hills divide;" fig. 1B) formed in the core of a north-trending arch of upper-plate volcanic and sedimentary rocks on Proterozoic basement rocks (Faulds and others, 2000). The antiformal character of this feature is interpreted as warping from the convergence of roll-over folds in opposing normaloffset faults in southern Cottonwood and northern Mohave Valleys (Faulds and others, 2000). The crest of the arch is eroded through the Miocene cover to expose a distinctive, crag-forming Proterozoic megacrystic granite. Davis Dam (completed 1950-51) spans part of this feature to block the course of the Colorado River and create Lake Mohave. The breaching of the Pyramid hills divide by floodwaters in the early Pliocene is key to deciphering the process by which the Colorado River ultimately integrated its course into the Gulf of California (House and others, 2005b, 2008b).

\section{Key Map Units Related to Arrival and Integration of the Colorado River}

This map area covers a part of Cottonwood Valley that contains particularly well exposed late Miocene, Pliocene, and Pleistocene strata. Those strata and related landforms and their associated soils are the focus of this map. Bedrock units that underpin the structural framework of the valley are not mapped, though structural features in the oldest exposed basinfilling sediments are described in Evidence for Faulting and Deformation.

Formal stratigraphic units in this map area that are critical to the history of the Colorado River include, in order of decreasing age, the Bouse Formation (unit Tbo; Metzger, 1968), the Bullhead Alluvium (unit Tcb; Howard and others, 2015; House and others, 2005b), and the Chemehuevi Formation (unit Qch; Malmon and others, 2011). Several informal and subsidiary units identified in this map area add critical details to the story. Chief among these are the late-extensional beds of Nellis Wash (unit Tnw) and the mostly post-extensional upper Miocene beds of Lost Cabin Wash (unit TIc), both pre-river units, and deposits of the late Pleistocene Riverside alluvium (unit Qcr), which form the youngest Colorado River deposits found above the surface of Lake Mohave. The youngest parts of unit Qcr are below the surface of the lake, and the Blythe Alluvium (Block and others, 2019) spans most of the submerged valley floor. 


\section{Late Miocene Pre-Integration Valley-Axis Deposits}

The beds of Nellis Wash (unit Tnw) and the overlying beds of Lost Cabin Wash (unit Tlc) are two mostly fine grained late Miocene axial-valley deposits that track the slowing and cessation of significant extensional tectonic activity in Cottonwood Valley before the arrival of the Colorado River (Faulds and others, 2001). These units are similar to and coeval with upper parts of the 10.6-5.9 Ma Muddy Creek Formation, which is found in several basins to the north (Bohannon, 1984; Beard and others, 2007). Limited outcrops of the beds of Nellis Wash are present in the northern part of this map (fig. 2). The unit is named for a series of more extensive exposures of mostly flat lying strata found in and near Nellis Wash in the Spirit Mountain NW 7.5' quadrangle, adjacent to the northwest corner of this map (House and Faulds, 2009), although they did not distinguish these deposits from the beds of Lost Cabin Wash.

The beds of Nellis Wash (unit Tnw) are composed of a sequence of mostly mildly deformed fine-grained siliciclastic deposits. The unit is faulted and mildly tilted locally, and it overlies a sequence of faulted and moderately to steeply tilted alluvial fan deposits. Most of the underlying fan deposits in the map area appear to be sourced from the Black Mountains, but clasts with characteristics of the Newberry Mountains are present in some strata. The underlying fan deposits beneath beds of Nellis Wash on the west side of the valley northwest of the map area are predominantly derived from the Newberry Mountains.

The beds of Nellis Wash (unit Tnw) are overlain by broadly similar looking younger basin-fill deposits of the beds of Lost Cabin Wash (unit TIC). In this map, the two are separated by relatively coarse grained axial-wash deposits containing interstratified sediments (unit Tfco; fig. 3) derived from mountain sources on both sides of the valley. We interpret unit Tfco as part of a fluvial system (wash) that drained north to a playa in central Cottonwood Valley from a divide formed in large coalescing alluvial fans and probably the Pyramid hills divide near the southern end of the valley (fig. $1 B$ ).

The overlying beds of Lost Cabin Wash (unit Tlc) comprise a series of late Miocene to early Pliocene valley-filling mudstones, sandstones, and minor gravel deposits (fig. 4). The unit is mildly deformed to mostly undeformed. The beds of Lost Cabin Wash are dominated by a mostly fine grained basin-fill facies that includes several tephra layers and paleosols. Locally, the fine-grained deposits of the beds of Lost Cabin Wash coarsen and grade laterally into alluvial-fan and wash deposits from piedmont areas flanking the paleovalley bottom (unit Tfb1).

Constraints on the age of the uppermost beds of Lost Cabin Wash (unit Tlc) are important, because the top of the unit was the floor of Cottonwood Valley immediately prior to the arrival of the Colorado River into the valley. In each valley along the lower Colorado River corridor, the arrival of Colorado River water is recorded by the first deposits of the Bouse Formation (figs. 5, 6). Thus, the minimum age of the uppermost beds of Lost Cabin Wash is the maximum age of Colorado River arrival to this area and to all points downstream, including the Gulf of California.

The beds of Lost Cabin Wash (unit Tlc) contain numerous tephra layers in steep bluff exposures of the unit that flank Lost Cabin Wash and several informally named washes farther north in the map including "highwall wash" and "odyssey wash" (House and others, 2008a; Crow and others, 2018). A combination of direct dating of sanidine in tephra deposits, tephrochronologic correlation, and paleomagnetic analysis constrain the minimum age of the uppermost beds of Lost Cabin Wash. The stratigraphically highest tephra found in the beds of Lost Cabin Wash in "highwall wash" recently yielded a radiometric age of $5.37 \mathrm{Ma}$ (Crow and others, 2018, 2019a). Magnetostratigraphic data (Schwing, 2019) indicate that this tephra underlies a

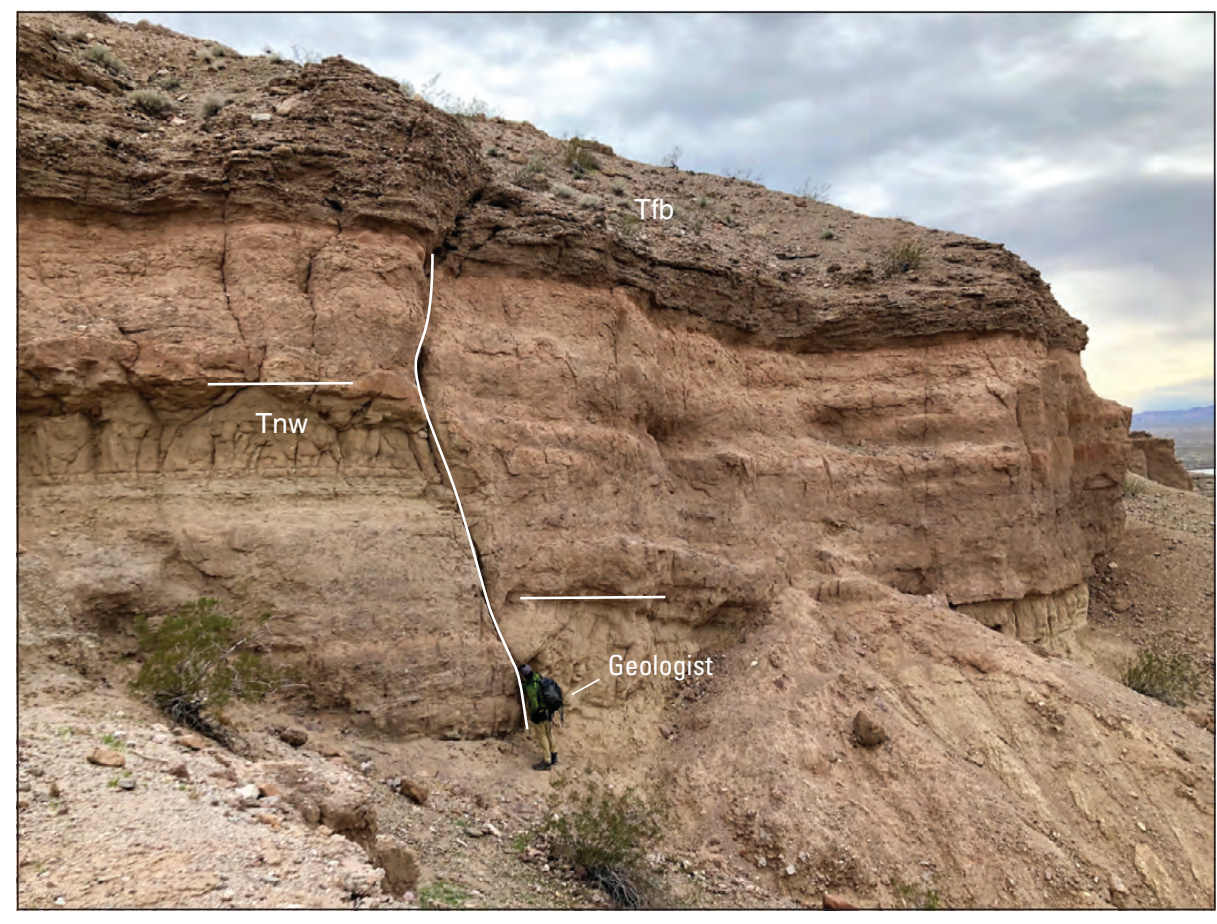

Figure 2. The beds of Nellis Wash (unit Tnw) near Cactus Cove. Here the unit is relatively flat lying and cut by a steep fault with at least $3 \mathrm{~m}$ offset. Reference lines are shown to indicate local offset along the fault. The beds of Nellis Wash are overlain unconformably by unit Tfb, which appears to be minimally offset at this site. 


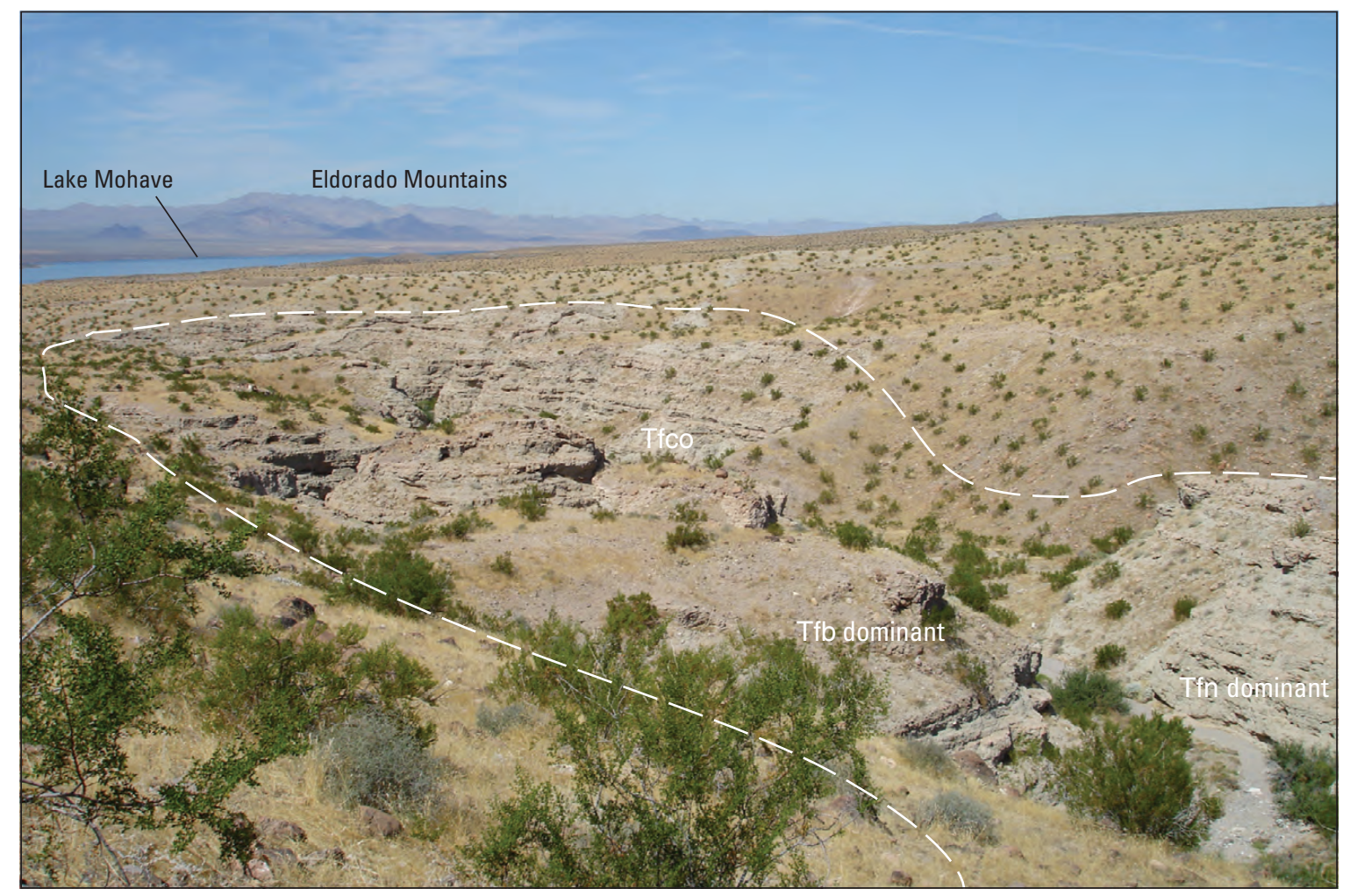

Figure 3. View to northwest across slot canyon formed in older paleochannel-fill conglomerate (unit Tfco), looking toward Lake Mohave and Eldorado Mountains, Nevada. Differences in the relative predominance of lithologies from either side of the valley correspond to greenish-gray strata (unit Tfn, Newberry Mountains source dominant) and light-reddish-brown strata (unit Tfb, Black Mountains source dominant).
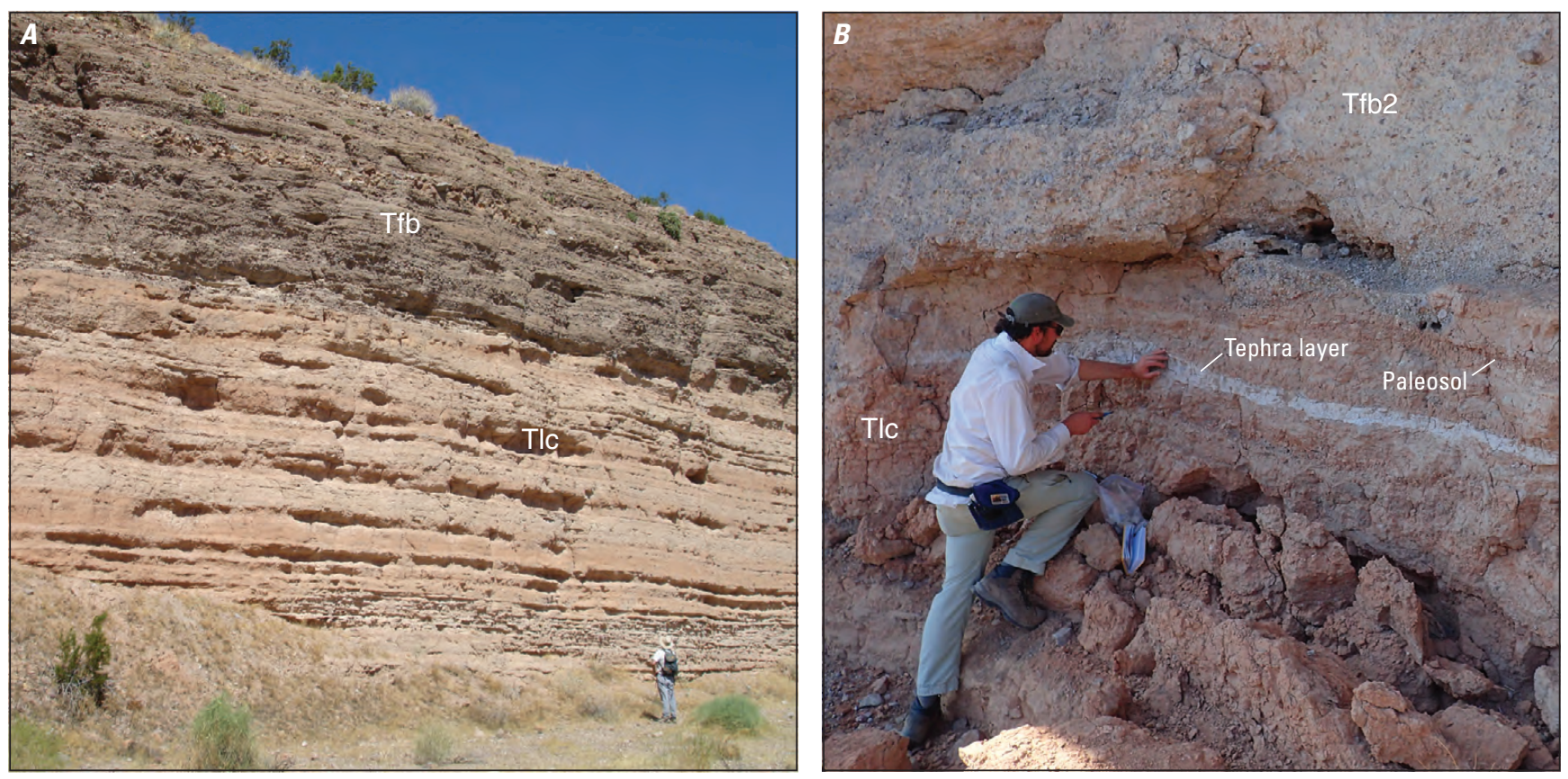

Figure 4. A, Relatively thick sequence of beds of Lost Cabin Wash (unit Tlc) under fanglomerate of Black Mountains (unit Tfb) in the north-central part of the map area. Thin beds with reworked calcareous sediments of the Bouse Formation are common in the lower few meters of the fanglomerate. $B$, The 5.37-Ma tephra layer (Crow and others, 2018, 2019a) in the upper part of the beds of Lost Cabin Wash in the informally named "highwall wash," overlain by younger and paleosol-bearing beds of Lost Cabin Wash that are cut by the fanglomerate of Black Mountains (unit Tfb2). 
reverse- to normal-polarity transition correlated to the beginning of the Thvera Subchron (5.24 Ma), indicating that the upper beds of Lost Cabin Wash and the overlying Bouse Formation are younger than 5.24 Ma. Tephra beds farther down in the stratigraphic section yielded late Miocene ages (House and others, 2008b).

\section{Bouse Formation}

The Bouse Formation (Metzger, 1968) is a basin-filling deposit of limestone, mud, and sand that is found in the string of basins along the lower Colorado River corridor from Hoover Dam to Yuma, Arizona (Metzger and others, 1973; Metzger and Loeltz, 1973; Olmstead and others, 1973). The Bouse Formation is the primordial deposit of the Colorado River, and its deposits record a sequence of lake filling and spilling, first with water then followed by sediment (House and others, 2008b; Pearthree and House, 2014). Lake development by inundation with soluterich Colorado River water is recorded in a basal carbonate facies that includes marl (calcareous mudstone) and travertine; a nearshore facies including cross-bedded nearshore deposits of calcarenite, sandstone, and local gravels; and fan-delta deposits from large local tributary drainages. The core of the Bouse Formation includes thick siliciclastic deposits of mostly Colorado River derived mud and sand that partially filled Cottonwood and Mohave Valleys with lacustrine and deltaic sediment (Lucchitta, 1972; Buising, 1990; House and others, 2008b; Pearthree and House, 2014).
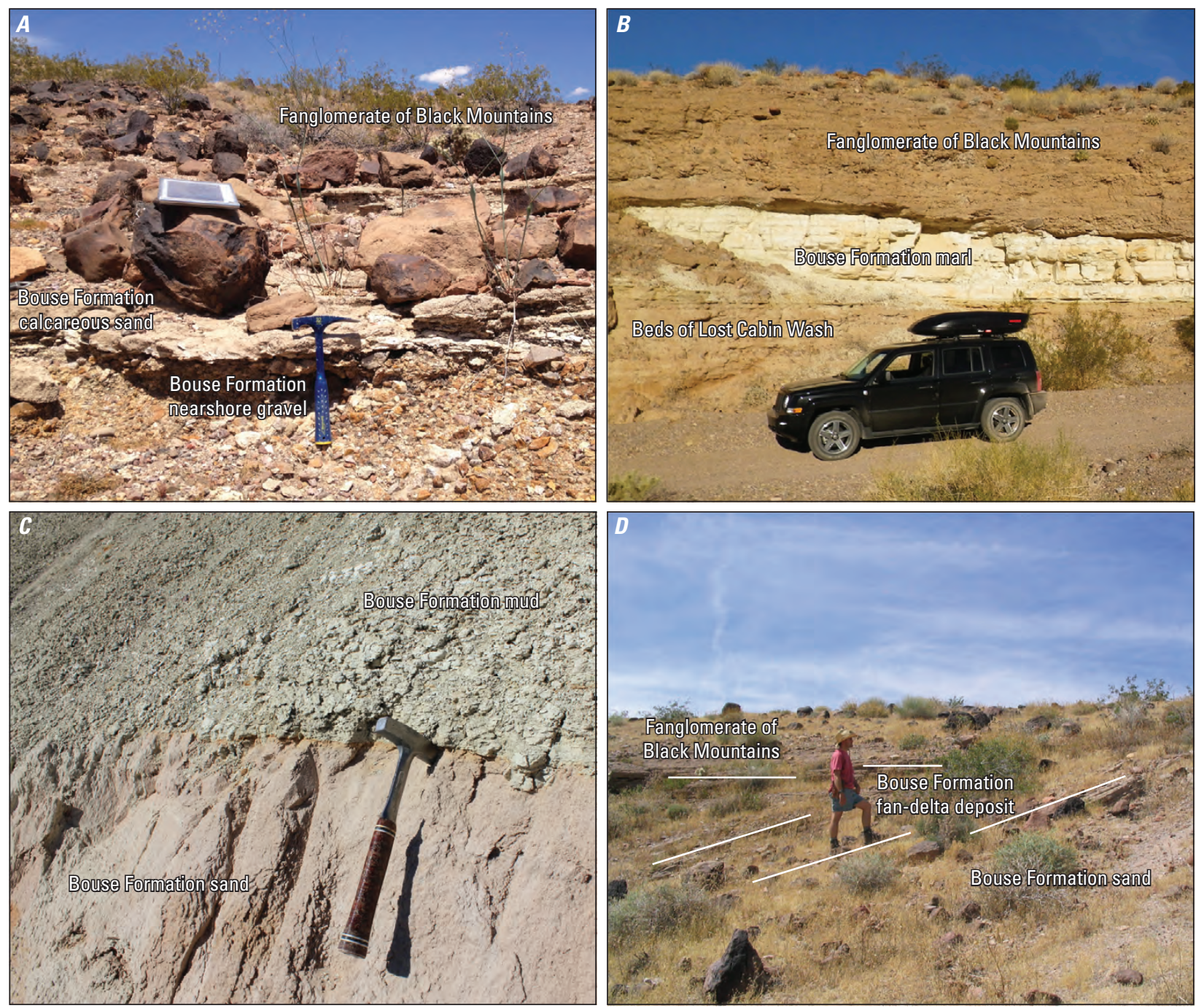

Figure 5. Key facies of the Bouse Formation in the map area. $A$, Nearshore wave-worked gravel capped with calcareous sandstone in unit Tbogg. Gravel backsets near base of hammer are dipping away from the valley axis. $B$, Bouse Formation marl (unit Tbocm) sandwiched between beds of Lost Cabin Wash (unit TIc) and fanglomerate of Black Mountains (unit Tfb2). C, Exposure of Bouse Formation siliciclastic deposits (unit Tbos) in Granite Wash, Arizona. This typical sequence of pinkish-brown Colorado River sand capped with greenish-gray Colorado River mud conformably overlies Bouse Formation marl (unit Tbocm) at this site. $D$, Isolated exposure of tributary fan-delta deposit that bevels Bouse Formation siliciclastic deposits (unit Tbos). Topset and foreset beds of locally derived calcareous sand and fine-grained gravel are delineated with white lines. This unit is analogous to unit Tbz in Gootee and others (2016). 

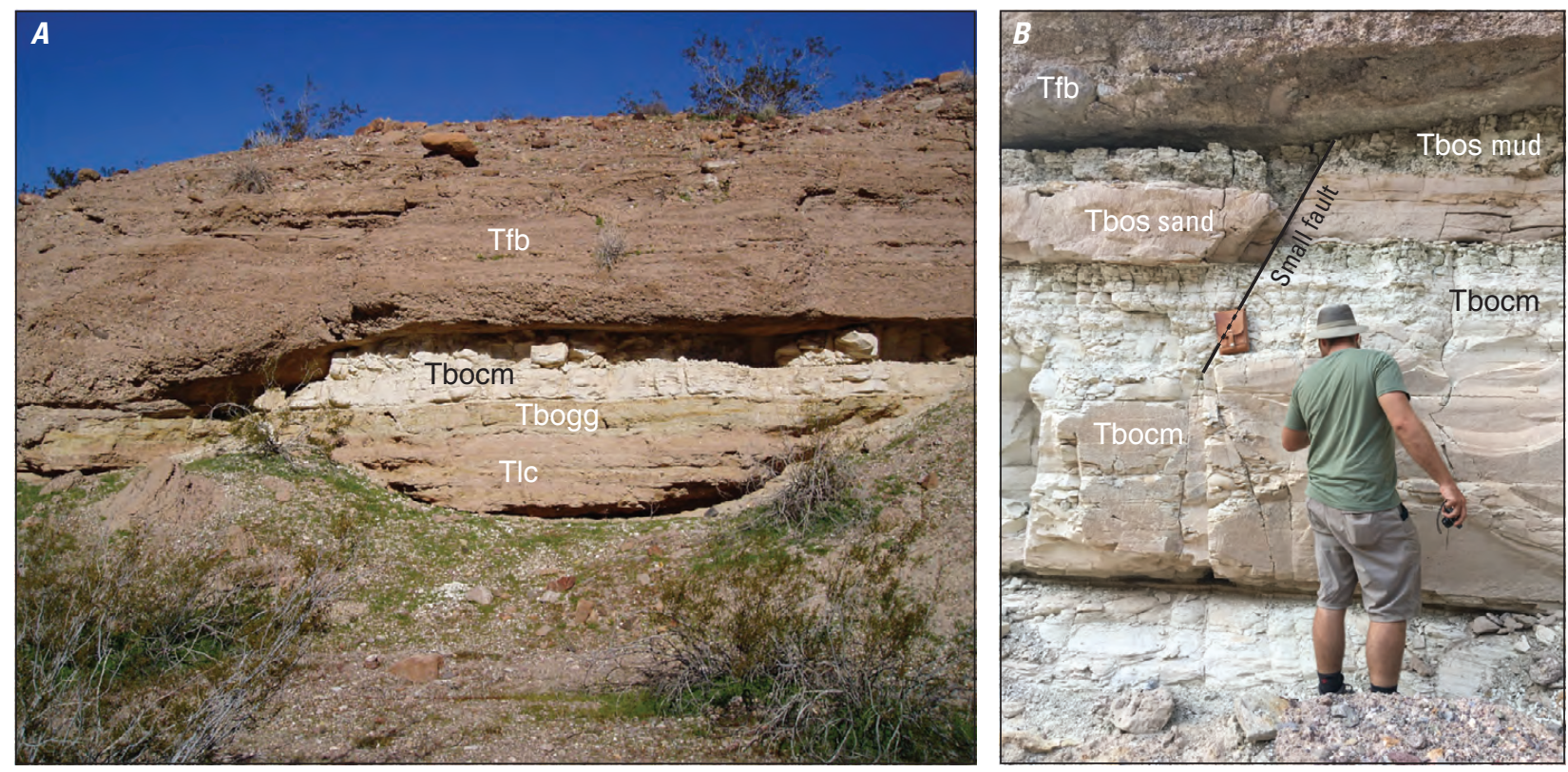

Figure 6. A, Bouse Formation marl (unit Tbocm) sandwiched between fanglomerate of Black Mountains (unit Tfb, top) and beds of Lost Cabin Wash (unit TIc, bottom). Note the yellowish-brown oxidized layer (unit Tbogg) of mildly wave worked sediment at the base of the marl. The well-exposed and labeled Bouse Formation and beds of Lost Cabin Wash interval is approximately $2 \mathrm{~m}$ thick. $B$, Bouse Formation marl (unit Tbocm) overlain by bedded sand and mud of unit Tbos in the Lost Cabin Wash, Arizona, area. Small-displacement fault is evident near the field book case.

The arrival of the Colorado River into Cottonwood Valley initially filled a shallow lake that was dammed at the Pyramid hills divide (House and others, 2005b, 2008b). This dam failed catastrophically into the north end of Mohave Valley and ultimately created a much more extensive and deeper lake that inundated both valleys from damming at the Topock divide at the southern end of Mohave Valley (fig. 1B; House and others, $2005 \mathrm{~b}, 2008 \mathrm{~b}$ ). As described previously, the age of the Bouse Formation in Cottonwood Valley is less than 5.24 Ma based on dated ash beds and magnetostratigraphy in the upper part of its substrate, the beds of Lost Cabin Wash (unit TIc). Farther south in the river corridor near Cibola, Arizona, the basal carbonate of the Bouse Formation contains the 4.8-5.0 Ma Lawlor Tuff (Sarna-Wojcicki and others, 2011; Harvey, 2014). Thus, Bouse Formation deposition in the lower Colorado River corridor lasted for less than $440 \mathrm{ka}$, likely much less.

This map area includes some of the northernmost and highest-standing outcrops of the Bouse Formation in the Colorado River corridor (figs. 5, 6), although possible correlative deposits have been identified in the Boulder basin-Frenchman Mountain area farther north in the Lake Mead area (Roskowski and others, 2010). The Bouse Formation deposits are concentrated in the northeastern part of the map area and include small remnants of locally derived nearshore gravel deposits with interbedded travertine (also called tufa) layers (fig. $5 A$ ), basal marl (fig. $5 B$ ), fine-grained siliciclastic deposits from the Colorado River (fig. $5 C$ ), and rare tributary fan-delta deposits (fig. $5 D$ ).

The Bouse Formation marl (Tbocm) was first precipitated from and deposited by solute-rich waters encroaching onto the paleovalley floor (unit TIc) and toes of alluvial fans along the valley margin (unit $\mathrm{Tfb} 1$ ), which were reworked as nearshore sediment in some areas (Tbogg). Figure $6 A$ shows an example of each of these Bouse Formation facies sitting on the beds of Lost Cabin Wash. Well-preserved and exposed basal carbonate deposits rest on the remnants of late Miocene fans emanating from the Black Mountain tributaries of Portland, Granite, and Lost Cabin Washes (see cross section $B-B^{\prime}$ on map sheet). An ensuing influx of Colorado River sediment into the basin is recorded in accumulations of Bouse Formation mud and fine sand in the topographic troughs between the fans (fig. 5C), sometimes in close association with carbonate facies (fig. $6 B$ ). These deposits include interbeds of greenish-brown mud and pinkish-gray fine-grained Colorado River sands, likely deltaic deposits that are typical of each valley along the lower river corridor. The detrital zircon signature of Bouse Formation sands from samples in this map area confirm a Colorado River derivation (Kimbrough and others, 2015).

\section{Bullhead Alluvium}

The Bullhead Alluvium is a thick package of Colorado River sediment that records the culmination of the river's integration with the Gulf of California in the early Pliocene and an accompanying erosional pulse in its watershed (Howard and others, 2015). Metzger and Loeltz (1973) designated Bullhead Alluvium sediments as a major constituent of their unit B. A well-exposed stratotype of the Bullhead Alluvium, as defined by Howard and others (2015), is in the south-central part of this map in an approximately $4-\mathrm{km}^{2}$ area centered around the lower part of Tyro Wash (fig. 7). Exposures in Tyro Wash and areas to the north include excellent exposures of nearly $200 \mathrm{~m}$ of elaborately cross-bedded, quartz-rich sand; thick, tabular beds of rounded cobble gravel; lenses of boulder and cobble 

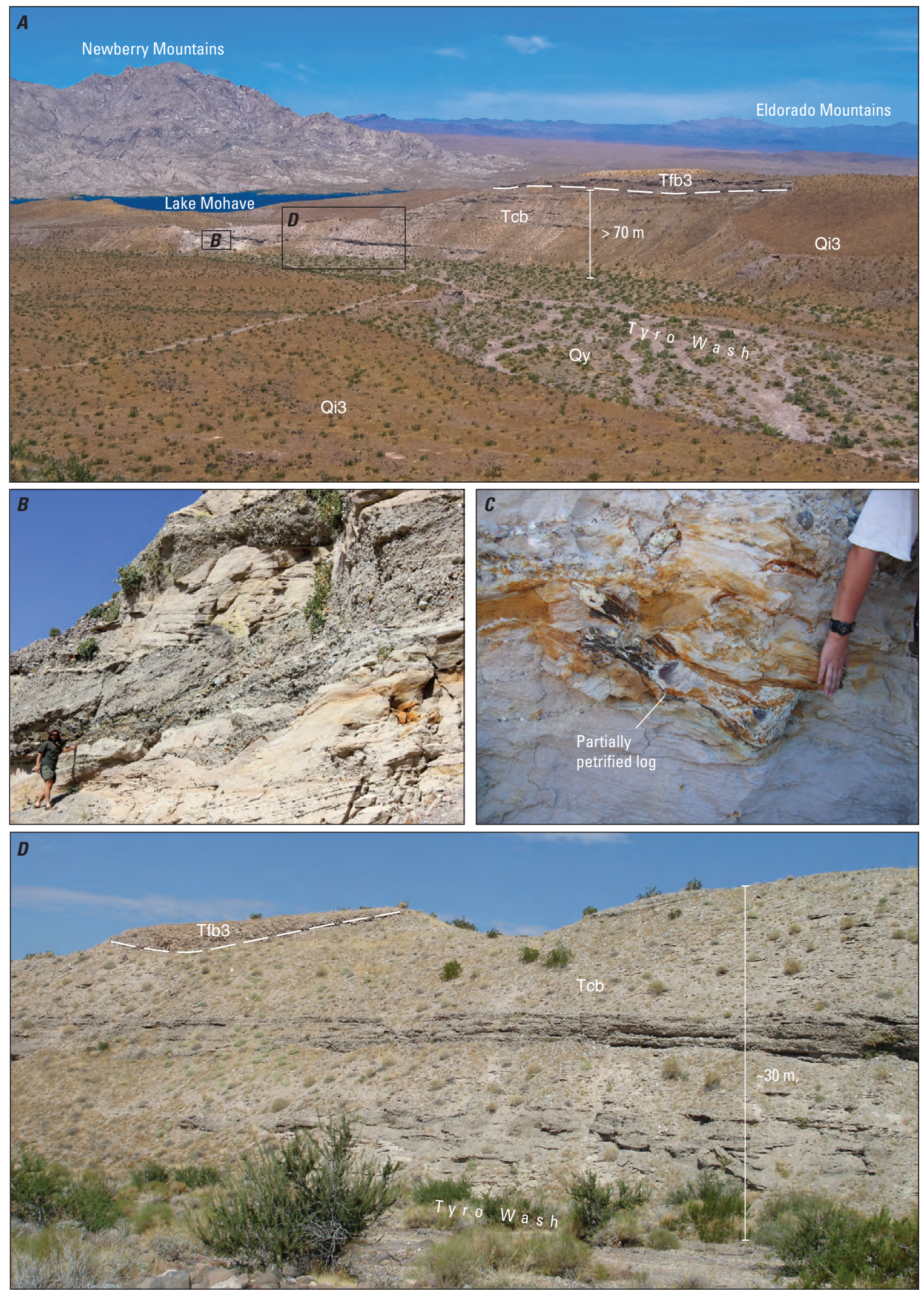

Figure 7. Various views of the Bullhead Alluvium (unit Tcb) in Tyro Wash and nearby areas. A, View of 70-m-thick unit Tcb exposure along the north side of Tyro Wash, Arizona (stratotype area described by Howard and others, 2015). Tfb3, fanglomerate of Black Mountain, unit 3; Qi3, intermediate piedmont alluvium, unit 3; Qy, young piedmont allumium, undivided. $B$, Detail of complexly structured unit Tcb sand and gravel deposit in Tyro Wash. C, Example of a partially petrified log in oxidized unit Tcb sand at a site in informally named "scoop wash" just south of Tyro Wash. This petrified log is found in discolored sand deposits similar to the orange sand at the right edge of figure $5 B$. $D$, Closer view of 30-m-thick section (unit Tcb) including thick, tabular beds of strongly consolidated pebble-cobble conglomerate interbedded with relatively loose sand and fine gravel in Tyro Wash. Tfb3, fanglomerate of Black Mountain, unit 3. 
conglomerate (fig. 8); and minor amounts of mud. Interbedded fanglomerates from the lithologically distinct mountain sources on each side of the valley (units Tfn and Tfb2) help define the swath of the Bullhead Alluvium channel system in the map area, and interbedded lenses of Bullhead Alluvium sand in fanglomerates help define the width and composite thickness of the unit (fig. 9).

The age of the Bullhead Alluvium is approximately 4 Ma with a range between 3.5 and 4.5 Ma (Howard and others, 2015). The $>3.59$ Ma tuff of Artists Drive of Knott and others $(2008,2018)$ is present in fanglomerate deposits interbedded with the upper part of the Bullhead Alluvium at nearby sites in both valleys (House and Faulds, 2009; House and others, 2008b; Pearthree and others, 2009), and the 3.3-Ma Nomlaki Tuff Member of the Tuscan and Tehama Formations is found in alluvial fan deposits that unconformably overlie and are incised as much as $50 \mathrm{~m}$ into the upper parts of the Bullhead Alluvium (House and others, 2008b; Pearthree and others, 2009; Howard and others, 2015). The older boundary of the unit age is based on a 4.5 Ma (Faulds and others, 2016) lava interbedded with the lower part of the Bullhead Alluvium at Sandy Point in Lake Mead, approximately $170 \mathrm{~km}$ upstream of the map area.

The stratigraphic base of the Bullhead Alluvium is not exposed in the map area, but the unit can be seen to extend at
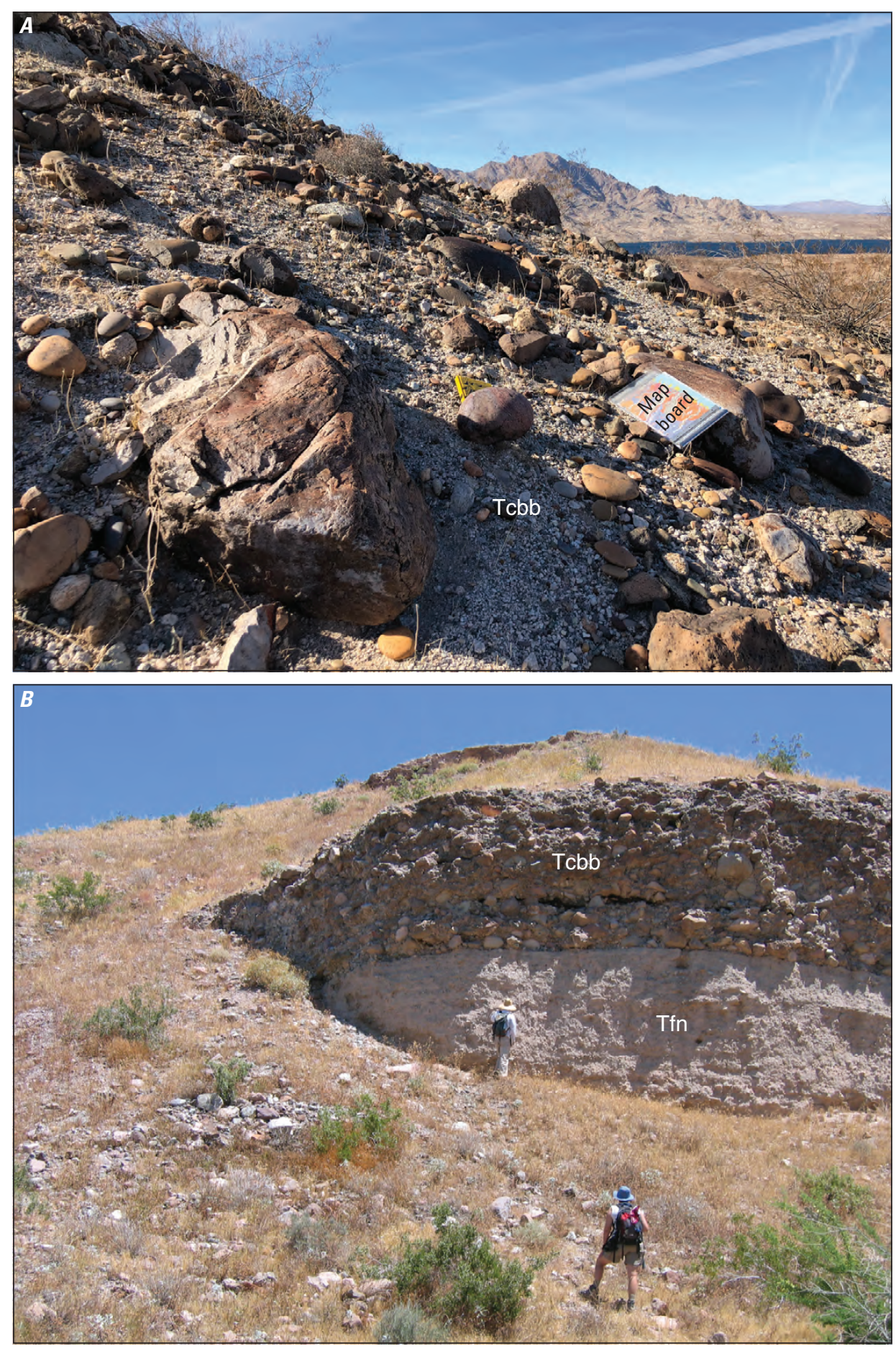

Figure 8. Boulder and cobble conglomerate (unit Tcbb) in the Bullhead Alluvium in Arizona part of map. A, Locally derived, varnished boulders of lightcolored granitic rocks from the Newberry Mountains (in west distance across Lake Mohave) mixed with far-traveled Colorado River cobbles weathering out of slope high in the landscape (field book and map board for scale). $B$, Boulder-filled paleochannel (unit Tcbb) carrying a mixture of fartraveled lithologies and local rocks from the Black Mountains sitting on light-colored late Miocene fanglomerate of Newberry Mountains (unit Tfn) low in the landscape. 
least 3-5 $\mathrm{m}$ into the clear waters of Lake Mohave in several places. The local base of the unit is well exposed and commonly associated with erosive paleochannel forms cut into underlying strata and bedrock (fig. 10). These paleochannel forms often include a coarse basal conglomerate deposited by the Colorado River. In White Rock Wash Cove, Nevada, a large locally sourced paleochannel (unit Tfcy) is interbedded with the Bullhead Alluvium near the shore of Lake Mohave. The Bullhead Alluvium is cut into the beds of Nellis Wash at this location (fig. $11 C$ ) and extends below the lake surface. Remnants of the unit Tfcy paleochannel can be traced up the piedmont of the Newberry Mountains for several miles. We interpret it as a piedmont tributary that formed during the interval of deep incision during the erosional interval separating the Bouse Formation from Bullhead Alluvium.

\section{Chemehuevi Formation}

The Chemehuevi Formation (unit Qch) is a greater than 100-m-thick late Pleistocene ( $70 \mathrm{ka})$ sequence of Colorado River mud, sand, and rare gravel. It is the most voluminous river deposit that postdates the Bullhead Alluvium. The stratotype of the Chemehuevi Formation (Malmon and others, 2012) is a few kilometers south of the map area in the northeastern part of the Davis Dam 7.5' quadrangle near Katherine Landing, Arizona (Faulds and others, 2005). Most Chemehuevi Formation deposits in the map area are beveled and covered by late Pleistocene alluvial fan remnants. A relatively thick and well exposed section of the Chemehuevi Formation near Desert Cove, Arizona, contains the $\sim 70$ ka Monkey Rock tephra bed of Malmon and others, 2011 (fig. 12B,C; Lundstrom and others,
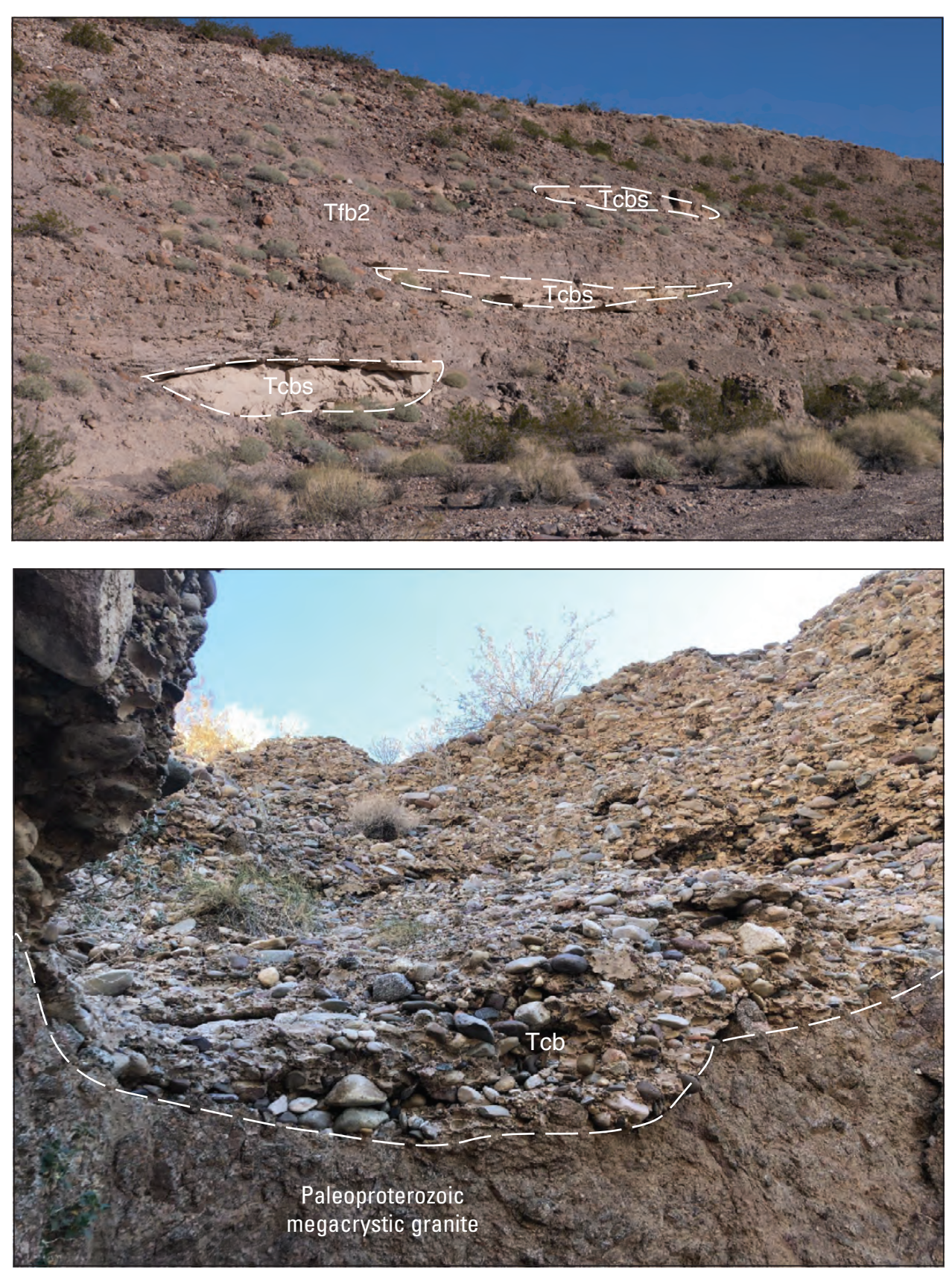

Figure 9. Lenticular beds (outlined) of Colorado River sands (Bullhead Alluvium, unit Tcbs) interbedded with fanglomerate of Black Mountain (unit Tfb2) in upper Tyro Wash, Arizona. Sand lens near bed of wash is approximately $1 \mathrm{~m}$ thick.

Figure 10. Bullhead Alluvium (Tcb) paleochannel cut into Paleoproterozoic megacrystic granite near the Arizona shore of Lake Mohave. Channel fill is a strongly consolidated coarse cobble conglomerate composed of mostly far traveled (exotic) lithologies. 

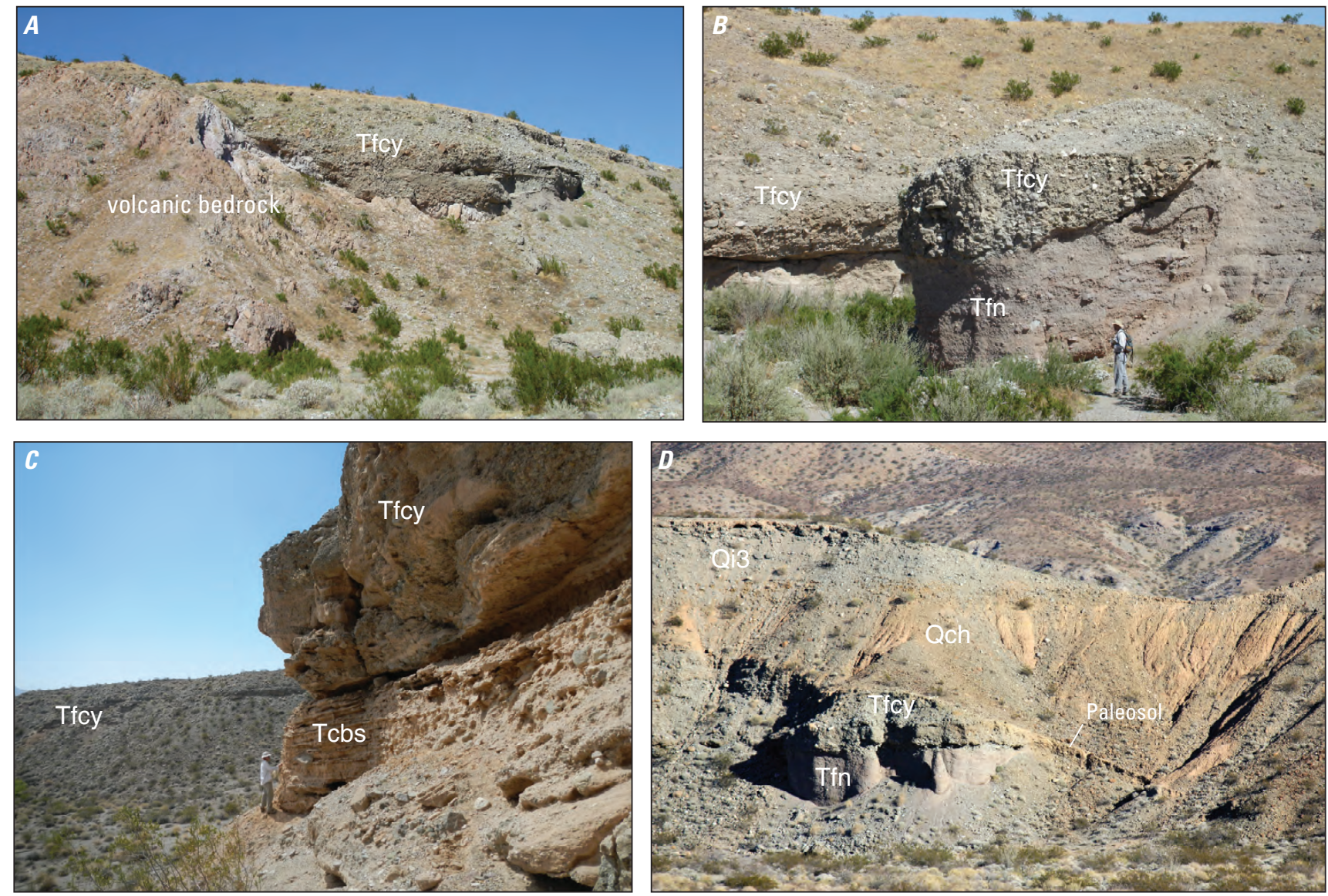

Figure 11. Examples of unit Tfcy. $A$, Gravelly, 12-m-thick paleochannel fill (unit Tfcy) cut into volcanic bedrock (unmapped) in lower White Rock Wash, Nevada. B, Paleochannel remnant (unit Tfcy) cut into tilted unit Tfn in tributary to White Rock Wash. C, View of unit Tfcy overlying and interbedded with sand of Bullhead Alluvium (unit Tcbs) near White Rock Wash Cove. $D$, Approximately 35-m-thick section showing unit Tfcy cut into unit Tfn (as in $B$ ) in lower White Rock Wash, Nevada. Here the unit is overlain by mud-rich facies of the Chemehuevi Formation (unit Qch), which is sitting atop a paleosol formed on erosional topography. Qi3, young piedmont alluvium, unit 3; Tfn, fanglomerate of Newberry Mountains.

2008), very near its base (House and others 2008a; Malmon and others, 2011). Remnants of the Chemehuevi Formation in the map area commonly fill erosional niches in older deposits and sit in buttress contact against deeply eroded paleo-landscape elements that host stage III calcic soils (terminology of Machette, 1985; figs. $11 D, 12 A$ ). This indicates that the greater than 100-m-thick Chemehuevi Formation aggradation event followed an interval of landscape dissection and prolonged (at least several ten thousands of years) subaerial exposure for which there is little other evidence. Paleosols below the base of the Chemehuevi Formation in the Arrowhead Cove area can be traced down to at least $225 \mathrm{~m}$ above sea level (asl), approximately $30-45 \mathrm{~m}$ below the highest extant Chemehuevi Formation remnants at nearby sites on both sides of Lake Mohave. Similar soils extend down to at least $200 \mathrm{~m}$ asl in the Laughlin, Nevada, area south of this map where the river surface is at approximately $150 \mathrm{~m}$ asl. The presence of moderately developed soils on relatively low lying and eroded landscape features indicates a period of prolonged subaerial exposure preceding the deposition of the Chemehuevi Formation. This marks a significant unconformity and associated soil-forming interval for which we have found no corresponding deposits of the Colorado River.

\section{Piedmont Tributary Deposits}

The geologic history of the mountain piedmonts is one of progressive aggradation during the period of active extensional deformation in the middle and late Miocene, followed by phases of punctuated aggradation and deep landscape denudation in response to drainage integration and Colorado River evolution. Piedmont deposits in the map area include a sequence of late Miocene to late Holocene sediments of alluvial fans and washes draining the Newberry and Black Mountains (see frontispiece). High-standing and deeply dissected alluvial-fan remnants are important secondary sources of piedmont alluvium for progressively younger deposits.

The scale and distribution of the suite of piedmont deposits is controlled by the size of contributing watershed, its lithology, and its relative elevation and distance from the valley axis. The latter factor is the most variable and is significantly influenced by the arrival of the Colorado River into the valley in the early Pliocene and by changes in its lateral and vertical position over time. This map spans a particularly narrow part of Cottonwood Valley as it transitions into Pyramid Canyon at its southern end, and the steep eastern face of the Newberry Mountains extends to the west shore of Lake Mohave. Consequently, fans on the 

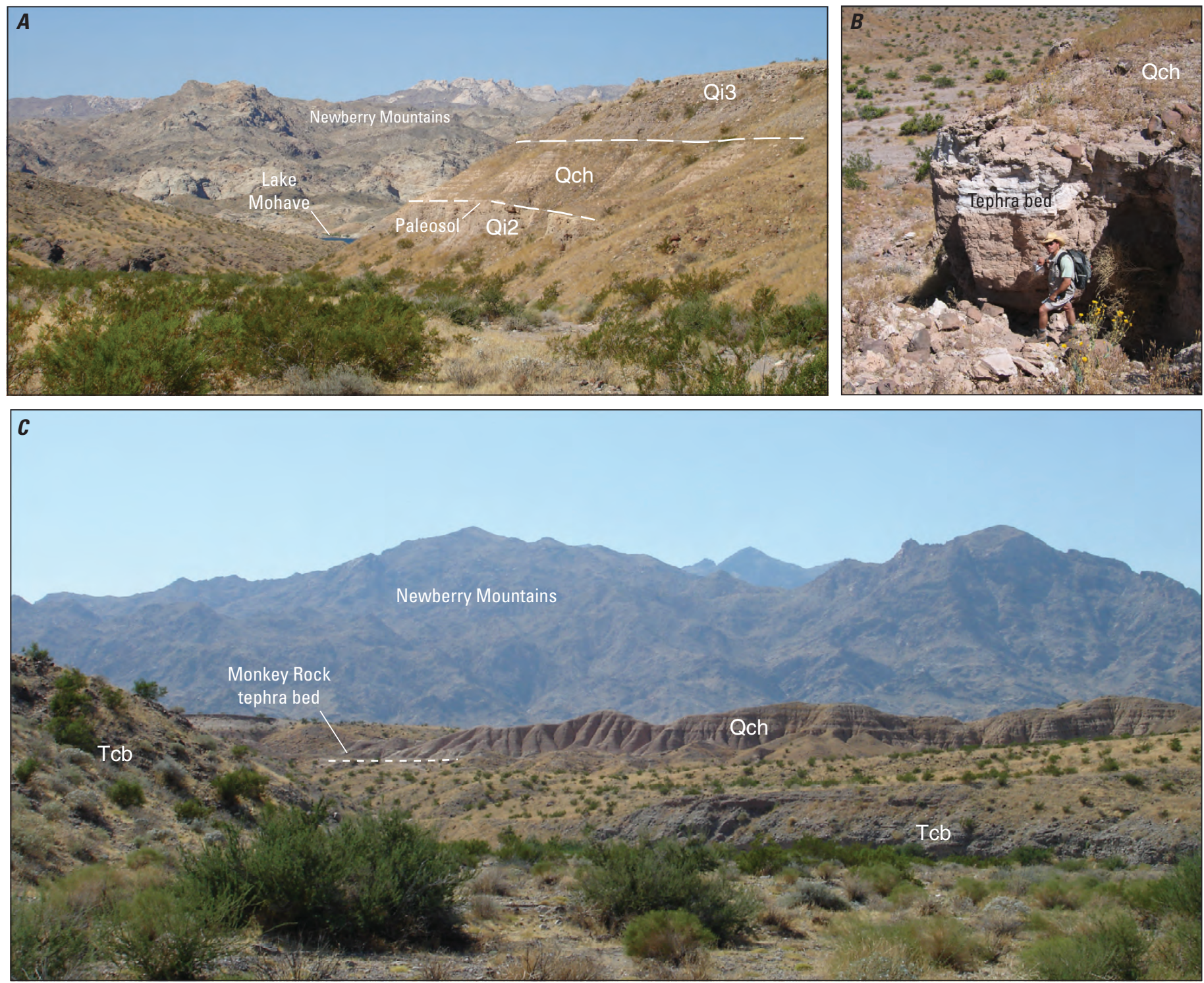

Figure 12. Chemehuevi Formation (unit Qch) in the map area. $A$, Sequence of Chemehuevi Formation capped with late Pleistocene alluvium overlying a paleosol in older tributary alluvium near Arrowhead Cove. Qi2, Qi3, young piedmont alluvium units 2 and 3. B, Thick bed of the Monkey Rock tephra bed of Malmon and others (2011) at the base of the Chemehuevi Formation. C, View of the largest unit Qch outcrop in the map area near Desert Cove. Location of the Monkey Rock tephra bed of Malmon and others (2011) is at the base of unit Qch at this site. Also note outcrop of cobble-rich Bullhead Alluvium (unit Tcb) in the middle ground and the steep face of the Newberry Mountains in the distance.

piedmont of the Black Mountains are deeply dissected and well exposed. Prior to the arrival of the Colorado River, alluvial fans from the Newberry Mountains (unit Tfn deposits from Empire and White Rock Washes, primarily) extended more than $1 \mathrm{~km}$ into what is now the Arizona part of the map; thus, the basin axis was east of the modern river (fig. 13).

This configuration prevailed during the aggradation of the Bullhead Alluvium, but when the Colorado River incised into the Bullhead Alluvium and related tributary deposits, its position became fixed at the base of the steep eastern face of the Newberry Mountains. The presence of the river nearer to the face of the Newberry Mountains than to the Black Mountains since Bullhead Alluvium deposition obviated the formation of extensive Newberry Mountains sourced fans on the west side of the map through the Quaternary. In contrast, alluvial fan deposits and landforms on the piedmont of the Black Mountains are extensive and track aggradation and degradation along the Colorado River from the late Miocene through the Holocene. Abandonment of alluvial fan surfaces and deep incision into the piedmont has been mostly controlled by base-level change forced by the river incision and aggradation, perhaps modulated by changes in sediment supply and transport capacity of tributary washes. A particularly distinctive suite of ancient alluvial fan deposits in the Arizona part of the map stands as high mesas, more than $100 \mathrm{~m}$ above the river/lake. These relict surfaces host extremely strongly consolidated, thick pedogenic calcretes with carbonate stages V-VI (Machette, 1985). These calcretes rank with some of the oldest soils preserved in the 
region (Brock, 2007; Brock and Buck, 2009; House and others, 2010). John S. Newberry (1861) identified and christened these features "the tablelands of the lower Colorado River" while chronicling natural history on an up-river expedition in 1857-58 led by J.C. Ives (1862). The specific area to which Newberry referred is shown in the photographs on the cover and figure 14 .

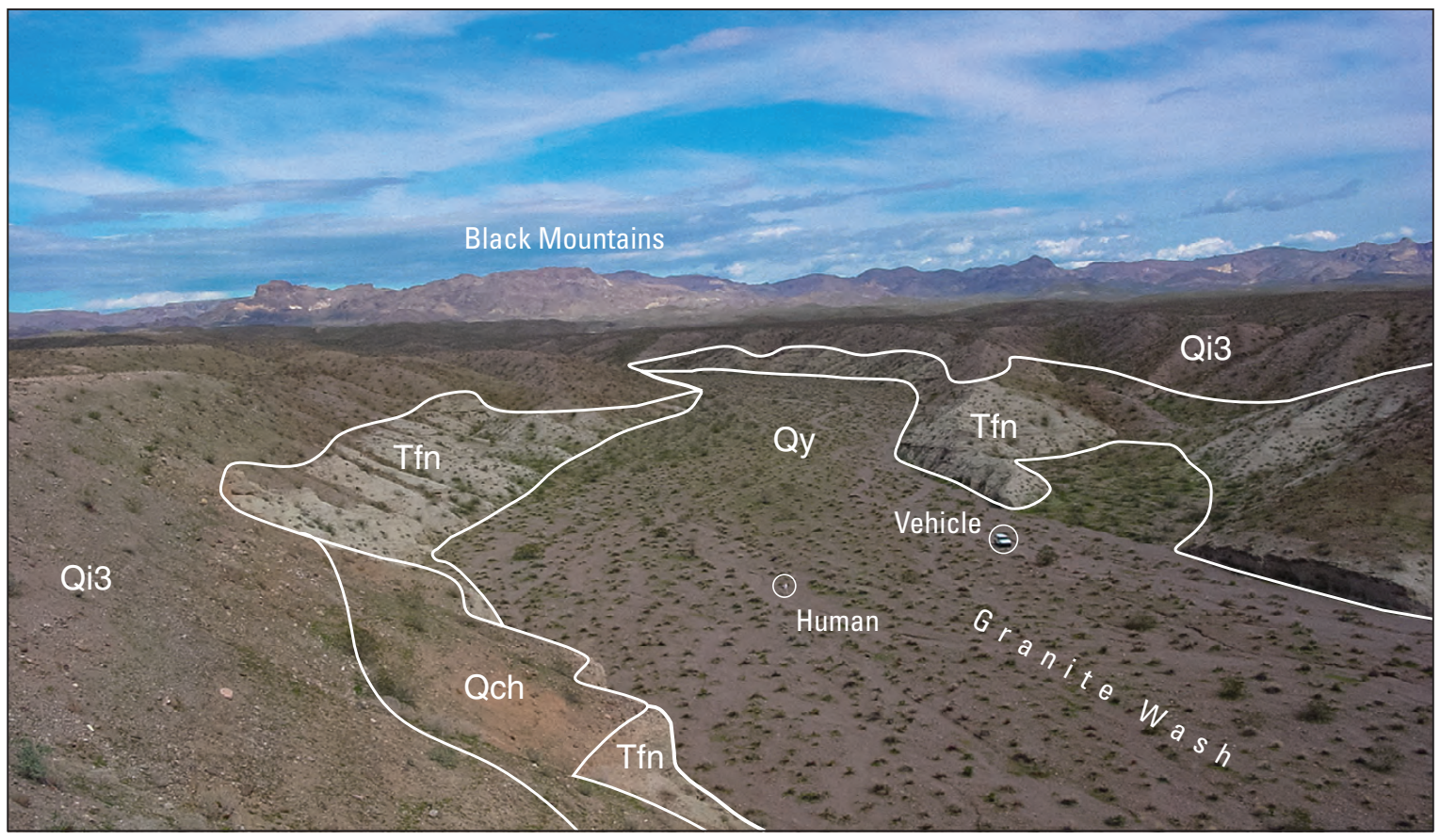

Figure 13. View to the east-southeast showing east-dipping beds of late Miocene fanglomerate of Newberry Mountains (unit Tfn) exposed in Granite Wash, Arizona. The fanglomerate is capped by late Pleistocene piedmont gravels (unit Qi3) of the Black Mountains (in background). Locally the Chemehuevi Formation (Qch) fills paleotopography between units Tfn and Qi3. See figures 12 and 15 and the map sheet for map expression of this relation. Qy, young piedmont alluvium, undivided.

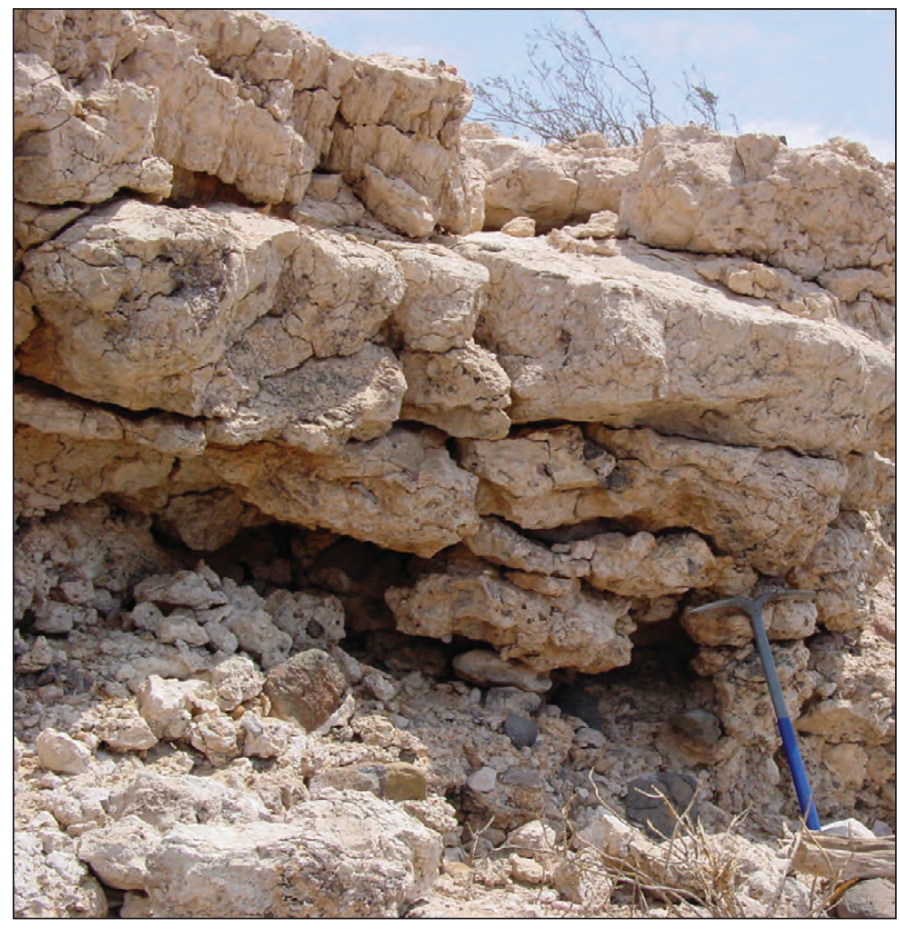

Figure 14. Massive stage VI Bkqm soil horizon on Pyramid mesa (unit QTbk1) that caps and includes mixed Colorado River and tributary gravel. It is possible that this soil records $>3$ m.y. of pedogenesis. The pick in lower right corner of photo is $65 \mathrm{~cm}$ long. 


\section{Summary of Late Neogene and Quaternary Evolution of Cottonwood Valley}

The geologic map (see map sheet) depicts the composite outcome of the transition of Cottonwood Valley from an isolated basin, likely floored by a dry playa, into a deep valley incised and shaped by the evolving Colorado River. Figure 15 shows the distribution of the late Miocene and Pliocene units in the modern landscape that tell this story.

The map in figure 15, based on the geologic map (see map sheet), has been simplified by removing the Quaternary deposits. In the following discussion, the map will be reconstructed in four major stages. Key aspects of each stage and their relation to map units will be described and somewhat reiterated from the previous section to help better understand the map, in particular the distribution of evidence for the early inception and evolution of the Colorado River. The late Chemehuevi stage (fig. $16 D$ ) adds the river during Chemehuevi Formation deposition to provide perspective on the nature of that river and also to emphasize that there is a nearly 4 m.y. unconformity in the river stratigraphy. There is scant direct evidence for the river's activity (other than erosion) between Bullhead Alluvium and Chemehuevi Formation deposition.

\section{Late Deposition of the Beds of Lost Cabin Wash ( 5.24 Ma)}

In the late Miocene, Cottonwood basin was part of a plexus of middle and late Miocene half-graben basins. These basins formed through extensional and transtensional tectonics in a zone extending west from the edge of the Colorado Plateau (Bohannon, 1984; Faulds and others, 2016). Each of the basins now along the course of the Colorado River shows a record of sedimentation from local sources during and following active extension. Some satellite basins in the Lake Mead area contain thick sequences of evaporite deposits that record decantation of intermittent yet large influxes of water from adjacent lake basins into aggrading playa systems. The youngest evaporite deposits upstream of Cottonwood Valley, in the Lake Mead area, contain a tephra layer (Faulds and others, 2016) that is very similar in composition to the 5.62 Ma tephra of Wolverine Creek found in the beds of Lost Cabin Wash (unit TIc) in Cottonwood Valley (House and others, 2008b). Cottonwood Valley, then, occupies a key position connecting the network of basins in the Lake Mead area with the north-to-south chain of basins in the lower Colorado River extensional corridor. Cottonwood Valley is also the northernmost basin in which the Bouse Formation has been confidently identified.

Figure $16 A$ shows the geologic setting of late deposition of the beds of Lost Cabin Wash (unit Tlc) toward the end of the Miocene when this part of Cottonwood Valley hosted a northflowing axial wash (unit Tfco) feeding an inferred playa system in central Cottonwood Valley (Pearthree and House, 2014). This was a common situation in the late Miocene in basins throughout the region (Faulds and others, 2016). The more eastern position of the late Miocene axial drainage is defined by interbedded alluvial fan strata from the lithologically distinct mountain sources on each side of Cottonwood Valley (Newberry Mountains, west side, unit Tfn; Black Mountains, east side, unit $\mathrm{Tfb}$ ). The southern, upper reaches of the Lost Cabin paleovalley are not well constrained, but the divide is likely to have included a combination of the Pyramid hills (fig. $1 B$ ) and coalescing alluvial fans from the Pyramid hills and from each side of the valley.

\section{Early Deposition of Bouse Formation ( $<5.24 \mathrm{Ma}$ )}

Abrupt and complete drainage reversal was initiated in Cottonwood Valley in the early Pliocene (after 5.24 Ma as indicated by Crow and others, 2018, 2019a) with the arrival of abundant, lake-forming Colorado River water (fig. 16B). A small, precursor lake filled to the level of the lowest divide in the valley. This divide at the downstream end of Cottonwood Valley failed catastrophically (House and others, 2005b, 2008b; Pearthree and House, 2014) to then form a much larger lake that would envelop and submerge most of both Cottonwood and Mohave Valleys. The significantly larger and deeper lake was held by a natural dam at the Topock divide at the south end of Mohave Valley (fig. 1B).

This representation (fig. 16B) shows the lake at its estimated maximum stage with the advancing delta front extending into the map area at the southern end of Cottonwood Valley. Siliciclastic deposits of mud and fine sand deposited out of suspension from plumes and density currents (turbidites) overlie submerged alluvial fans and fill topographic troughs between submerged alluvial fans. Carbonate sedimentation that was likely suppressed by turbid clastic input is sequestered to shoreline and inundated areas away from the active delta. There are exposures in the map area where fine to very fine Colorado River sand with interbedded Colorado River mud overlies marl (for example, Granite Wash, fig. 5C; Lost Cabin Wash, fig. 6B). Ample geologic evidence indicates that deltaic sedimentation eventually extended completely through Cottonwood Valley and to the south end of Mohave Valley to the area of Park Moabi (fig. 1B; Pearthree and House, 2014; Howard and others, 2019). The progradation of the river delta through the two valleys likely involved incision and telescoping of inset delta lobes as the Topock divide lowered in varying, some possibly large, increments (Pearthree and House, 2014).

\section{Late Deposition of Bullhead Alluvium ( 4 Ma)}

The late deposition of the Bullhead Alluvium (fig. 16C) corresponds to the time of maximum sediment filling by the Colorado River in the early Pliocene. Bullhead Alluvium fills a deep erosional unconformity that formed following the demise of the Bouse Formation lake system between Cottonwood Valley and the Gulf of California and the associated development of the basal profile of the river channel (see House and others, 2008b; Pearthree and House, 2014; Howard and others, 2015; and Crow and others, 2019b, for details). Exposures of the local base of the Bullhead Alluvium show that it is deeply 


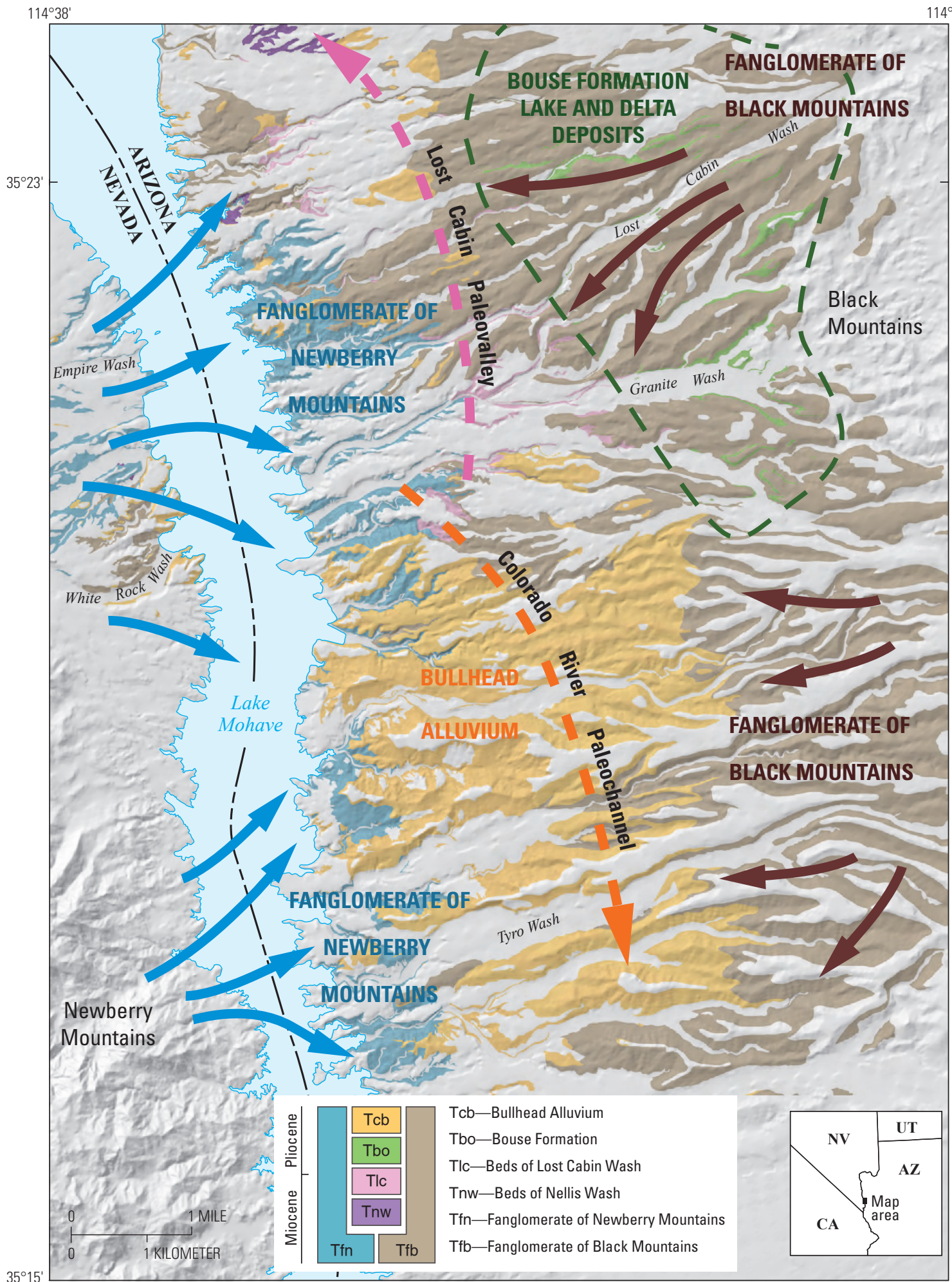

Figure 15. Geologic map of the late Miocene and Pliocene deposits in the Spirit Mountain SE 7.5' part of the map area, showing direction of sediment movement (arrows) from source. Younger river and piedmont units omitted for clarity. 

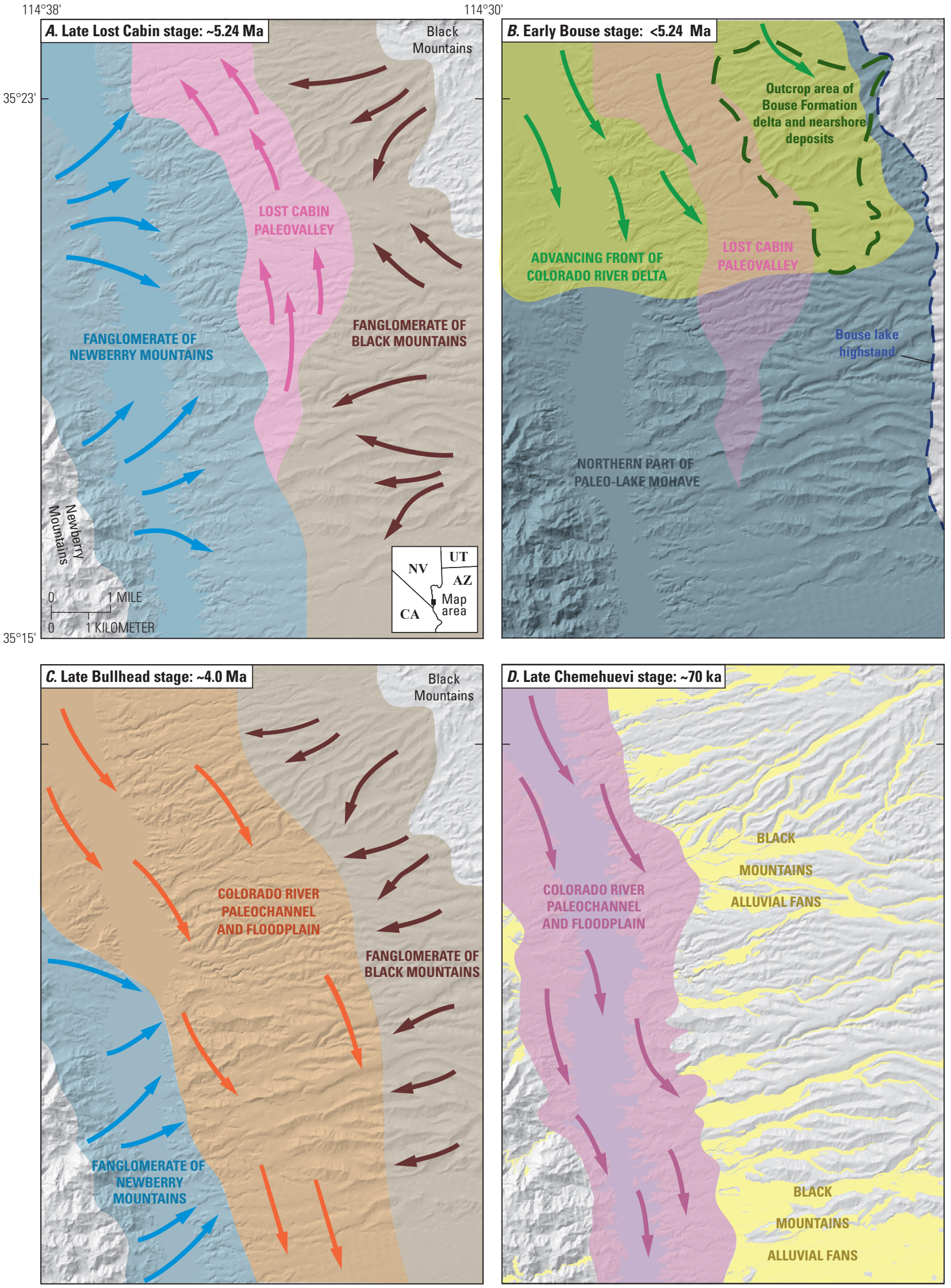

Figure 16. Late Miocene to Pleistocene paleogeography. Four main stages in the geologic evolution of Cottonwood Valley, including several episodes of deposition and erosion of huge volumes of Colorado River sediment (see text for detailed explanation). 
cut into the Bouse Formation and underlying units, including bedrock (fig. 9). Note, however, the Bullhead Alluvium extends at least $\sim 5 \mathrm{~m}$ below the lake surface and the true base of the unit has not been observed or described in well logs in Cottonwood Valley. The demise of the lake that inundated both Mohave and Cottonwood Valleys was followed by an episode of deep incision into the Bouse Formation and underlying sediments and then the arrival of a rapidly aggrading braided river channel of the early Colorado River. Interbedded alluvial fan deposits from the Newberry and Black Mountains help define the lateral extent of the Bullhead Alluvium channel system.

\section{Late Deposition of Chemehuevi Formation ( 70 ka)}

The late deposition of Chemehuevi Formation (fig. 16D) shows the general geologic character of the valley in the late Pleistocene, approximately 4 m.y. after the maximum aggradation of the Bullhead Alluvium depicted in figure 16C. The Colorado River deposited the Chemehuevi Formation in a deep valley that was carved into the Bullhead Alluvium fill and an array of older alluvial fan deposits. The Chemehuevi Formation aggradation was as thick as $170 \mathrm{~m}$ but occupies a narrower and more deeply inset position in the valley. Piedmont alluvial fan deposits that are coeval with the Chemehuevi Formation are shown in yellow and are mostly restricted to deeply incised valleys carved in older deposits. Note how the west side of the valley (western shore of Lake Mohave) abuts the southeastern face of the Newberry Mountains at this point in time. No significant alluvial fans extended from the southern Newberry Mountains into the valley axis for much of the Pleistocene. Instead, it appears that sediment being delivered by drainages from this steep part of the range was efficiently removed by the Colorado River.

\section{Evidence for Faulting and Deformation}

Late Cenozoic extensional and transtensional tectonics created the geologic and topographic framework of the corridor into which the lower Colorado River abruptly arrived near the beginning of the Pliocene (see review in Howard and others, 2019).

Cottonwood Valley is the northernmost alluvial valley in the corridor below Hoover Dam. It occupies a structural basin that was formed in the middle to late Miocene in an intense episode of regional crustal extension and related faulting. Faulds and others (2001) report robust age controls on synextensional strata from sites in the region of the map area that constrain the duration of most of the deformation between 15.8 and 11.3 Ma. They do also report, however, that activity in some areas, including Cottonwood basin, continued until about $9 \mathrm{Ma}$. Deformation within the map area is observed in the fanglomerate of Newberry Mountains (Tfn), fanglomerate of Black
Mountains (Tfb1, for example, fig. 17), beds of Nellis Wash (Tnw), beds of Lost Cabin Wash (Tlc), Bouse Formation marl (Tbocm), and Bullhead Alluvium (Tcb). Many of the units in the map area likely postdate middle Miocene detachment-style extension. Accordingly, fault density and displacement magnitudes appear to wane in younger units, and deformation has not been observed to affect Pleistocene piedmont or river deposits in this map area.

All documented faults display a variety of slickenline orientations. The mean plane calculated for all fault orientations (strike, dip) measured is $191^{\circ}, 84^{\circ} \mathrm{W}$. (fig. 17). Faults in units Tfn and Tfb1 are most common and generally exhibit centimeter- to meter-scale displacements and discontinuous strike lengths that are generally too short to be mapped at 1:24,000 scale. That said, a mapped fault in units Tfn and Tfb exposed in Tyro Wash and other small washes to the north exhibits $\geq 6-10$ $\mathrm{m}$ of throw and is oriented $185^{\circ}, 68^{\circ} \mathrm{W}$. Furthermore, multiple faults in units Tfb1 and Tnw show 1-6 m of normal-displacement throw within and to the south of "highwall wash" (for example, fig. 18). Depending on correlation of units, the largest fault in units $\mathrm{Tfb} 1$ and $\mathrm{Tnw}$ (oriented $013^{\circ}, 75^{\circ} \mathrm{E}$.) is inferred to have accommodated as much as $20 \mathrm{~m}$ of normal dip-slip motion just south of "highwall wash" and likely dies out to the north within "highwall wash." Faults cutting unit Tfn, exposed in the southern part of the map area, display slickenlines with rake values between $15^{\circ}$ and $90^{\circ}$, though generally moderate to high angle, and exhibit a mean plane of $160^{\circ}, 80^{\circ} \mathrm{SW}$. (fig. 17). Faults cutting unit $\mathrm{Tfb}$ exposed farther north display sparse slickenlines with high angle and mostly generally dip-slip rake values. These faults exhibit a mean plane of $214^{\circ}, 86^{\circ} \mathrm{NW}$. (fig. 17). The distribution of faults in unit Tfn to the south and faults in unit Tfb1 to the north may (1) echo the overall distribution of these deposits, (2) reveal something about fault timing, (3) simply be a factor of exposure, or, possibly, (4) some combination of the given factors. Note, however, that we are not certain about temporal correlation of these units in all cases. In unit Tlc, a subvertical northwest-striking fault in "highwall wash" displays crude subhorizontal slip fibers $\left(\right.$ rake $=08^{\circ}$ ) with ambiguous shear sense and an unknown amount of offset, though presumably minor. The southeast segment of the fault in unit Tlc consists of three faults forming a zone approximately 7.5 $\mathrm{m}$ wide that resembles a negative flower structure with centimeter-scale displacements that show apparent-normal motion. This suggests a transtensional component of strain, though the ambiguous shear sense precludes clear determination of whether slip was dextral or sinistral. Continuation of the fault to the northwest is inferred in a subsidiary wash north of "highwall wash" and displays a fault zone $\leq 20 \mathrm{~cm}$ wide that is composed of two fault strands with centimeter-scale displacements. Each fault soles into a single subvertical fault at the outcrop base. The mean plane for the fault is $152^{\circ}, 89^{\circ} \mathrm{SE}$. (fig. 17). A thrust fault in unit Tlc oriented $160^{\circ}, 28^{\circ} \mathrm{W}$. with $15 \mathrm{~cm}$ of throw was observed in a small unnamed wash between the informally named "odyssey wash" and "highwall wash." 
A. Entire map area (all faults measured)
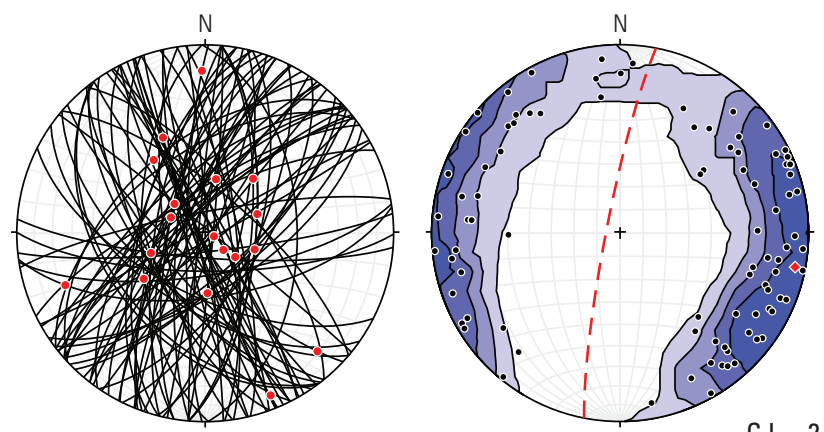

$\mathrm{n}=90$

$\mathrm{n}=17$

e1: $101 \% 06^{\circ}$

Eigenvalue: 0.6189
C.I. $=2$

S.L. $=3$

M.P. $=191,84 \mathrm{~W}$
B. Unit Tfb1 (Black Mountains fanglomerate, unit 1)
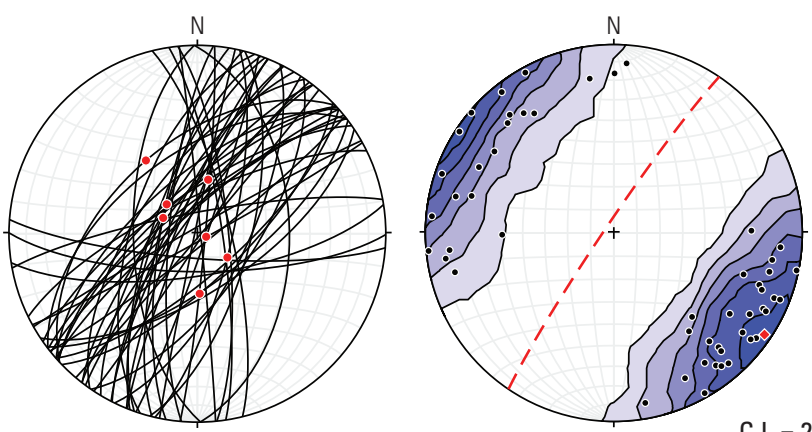

C.I. $=2$

$\mathrm{n}=51$

$\mathrm{n}=7$ e1: $124^{\circ} / 04^{\circ}$

S.L. $=3$

\section{Unit Tfn (Newberry Mountains fanglomerate)}

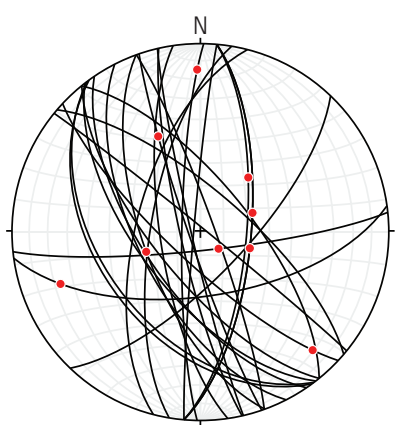

$\mathrm{n}=26$

$\mathrm{n}=9$

e1: $070^{\circ} / 10^{\circ}$

Eigenvalue: 0.7044

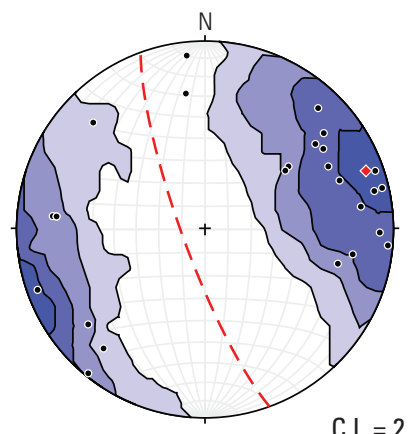

C.I $=2$

S.L. $=3$

M.P. $=160,80 \mathrm{SW}$

17. Stereonets of geometic and kinematic fault data collected in

\section{Unit TIc (Lost Cabin beds)}

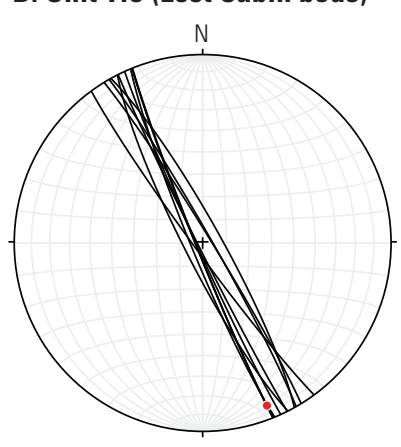

$\mathrm{n}=10$

$\mathrm{n}=1$

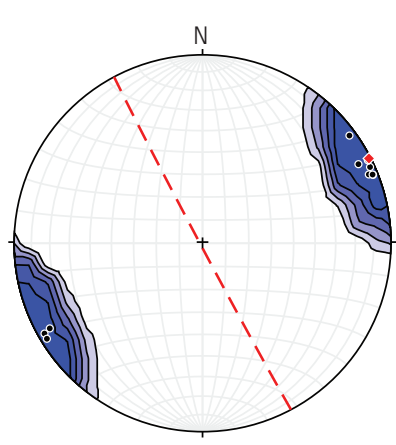

e1: $063^{\circ} / 01^{\circ}$

Eigenvalue: 0.9878 $\begin{array}{ll}\text { C.I. } & =2 \\ S . L & =1\end{array}$

S.L. $=1$

Figure 17. Stereonets of geometric and kinematic fault data collected in the map area. Stereonets at left in each pair show planes (black lines) and rake measurements of fault plane striae (red dots). Stereonets at right in each pair are Kamb contoured to show statistically significant populations of poles to planes (black dots). The contour interval (C.I.) for Kamb contours in each plot is 2 sigma (dark tone to light tone in plots indicates increasing departure from average). A significance level (S.L.) of 3 was used for each plot except for the unit Tlc plot (S.L.=1). The mean plane (M.P.) is determined from the maximum eigenvalue (e1) shown by the red diamond. $A$, All faults measured within the map area. This plot includes three small syn-depositional faults in unit Tbocm. Fault plane striae display dip-slip, obliqueslip, and strike-slip rakes. The mean plane shows predominant approximately north-striking faults, though this is a product of units Tfb1 and Tfn faults displaying markedly different geometric populations. $B$, Faults measured in unit Tfb1 display predominantly dip-slip rake measurements and strike northeast. The appearance of a northwest-striking strike-slip fault in unit Tlc could indicate transtensional-style deformation in the map area as young as $<5.24 \mathrm{Ma}$. Furthermore, diffuse east-west extensional strain is likely ongoing according to modern geodetic analyses coincident with the map area (Kreemer and others, 2010), though no discernible faulting was documented in young piedmont deposits. 


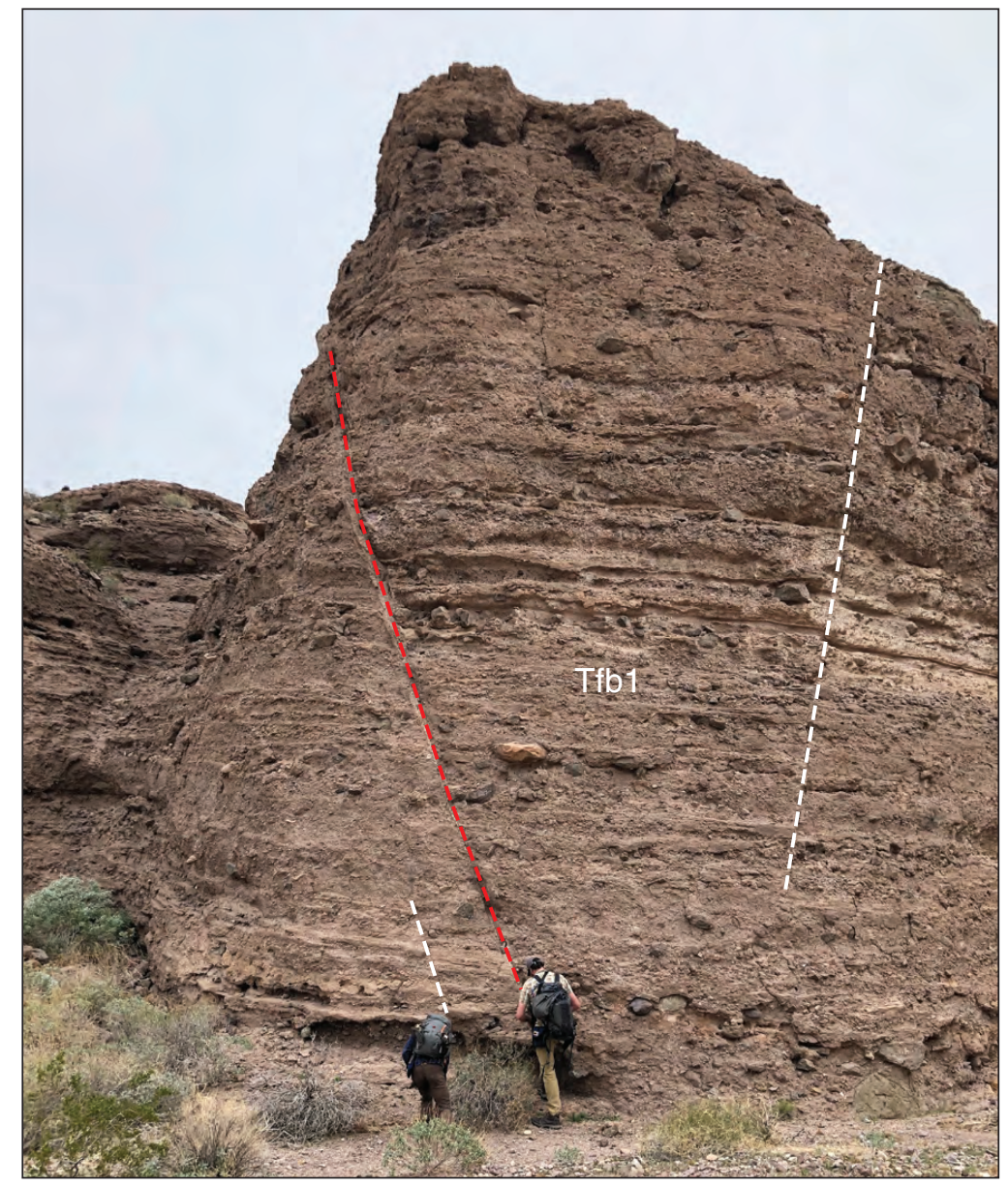

Figure 18. Steeply dipping fault in unit Tfb1 in lower "highwall wash" near Cactus Cove. Fault shown by red dashed line accommodates at least $6 \mathrm{~m}$ of normal offset down to the west (right). Possible faults with small offset shown as white dashed lines.

\section{DESCRIPTION OF MAP UNITS}

\section{SURFICIAL DEPOSITS}

Surficial deposits include all sedimentary deposits in the map area that postdate significant tectonic activity in the region and some deposits that record the waning stages of that activity (see Evidence for Faulting and Deformation). This period extends from approximately 8 Ma to the present (Faulds and others, 2001). Surficial deposits are mostly characterized by inset stratigraphic relations and their ages are presented as geochronologic (late, middle, early) as opposed to chronostratigraphic (upper, middle, lower).

\section{MISCELLANEOUS DEPOSITS}

d Disturbed ground (latest Holocene) - Includes artificial fill, constructed features, mine areas, and areas of artificial pavement

Qby Beach sediments of Lake Mohave (latest Holocene) - Wave-worked and moderately sorted to well-sorted, locally derived, re-worked gravel including subangular piedmont gravels and rounded river gravels. Low, concentric ridges as high as $0.5 \mathrm{~m}$ have been observed on some beaches. Lake Mohave is a reservoir created following the construction of Davis Dam between 1942 and 1951. Maximum thickness likely less than $5 \mathrm{~m}$

\section{PIEDMONT DEPOSITS}

Qls Landslide deposits (Holocene) - Very small and rare rock-topple deposits from mass failure of bluffs that flank relatively deeply incised washes. Deposits include piles of large angular blocks (up to about $5 \mathrm{~m}$ intermediate dimension) and related clastic debris that have detached and toppled from near-vertical bluffs formed in older, consolidated deposits (for example, units Tfb, Tfb3, Tfb2, Tfb1, Tlc). Only two such landslides have been mapped, one in Lost Cabin Wash and the north branch of "highwall wash." 
Features are small in areal extent, less than 0.1 hectares ( 0.25 acres). Neither slide was of sufficient scale to create full blockage of the washes. Smaller landslides of similar type are present in various places in the map area but have not been delineated. Maximum thickness less than $15 \mathrm{~m}$

Talus and colluvium (Holocene and Pleistocene) - Accumulations of clastic debris on steep slopes below various older map units. Most extensive deposits include accumulations on the steep flanks of the carbonate-soil-capped mesas (units QTbk, Qbk3, Qbk2, QTbk1) in the central part of the map. Maximum thickness likely less than $3 \mathrm{~m}$. Includes mixtures of cobble- to boulder-sized angular blocks of carbonate-cemented soil, Colorado River sand and gravel, and piedmont tributary gravels mixed with loose sediment. Some areas contain stable and moderately consolidated deposits that head on steep side slopes and are bound by moderate to strong soils with stage III carbonate horizons. These remnants commonly have discernible stratigraphic and geomorphic affiliation with piedmont unit Qi. Unit is more widespread than shown on map but not shown in detail to preserve clarity of relations among key Colorado River strata

Qy Young piedmont alluvium, undivided (Holocene to latest Pleistocene) - Poorly to moderately sorted gravel deposits of ephemeral washes and alluvial fans on the piedmonts of the Black and Newberry Mountains (for example, fig. 13). Characterized by fluvial channels and bars composed of locally derived gravel from the Black and Newberry Mountains and from large eroding remnants of abandoned alluvial fans and river deposits. This undivided unit is dominated by deposits that range in age from recent to middle Holocene and contain interspersed remnants of older piedmont deposits, including abandoned surfaces of unit Qy1

Qy2 Unit 2 (late to middle Holocene) - Alluvial deposits and related surfaces of ephemeral washes and alluvial fans that are frequently active or relatively recently abandoned. Deposits are composed of poorly to moderately sorted and bedded coarse sand and gravel and have well-defined channels, bars, and low terraces. Locally distinctive and relatively low lying paired and unpaired terraces are common. Well-preserved depositional topography and fabric, weak varnish possible. Very weak soil possible. Corresponds to unit Q4 of Dickey and others (1980). Thickness unknown, but not likely to exceed $5 \mathrm{~m}$

Qy1 Unit 1 (early Holocene to late Pleistocene)-The youngest likely fully abandoned alluvial deposits and surfaces. Unconsolidated sand, pebbles, cobbles, silt, and boulders. Surfaces have relict, weakly to moderately subdued depositional topography, lightly to moderately varnished clasts, and spatial or topographic detachment from the active fluvial environment, typically because of incision and less commonly owing to isolation related to channel migration. Soil development weak overall; calcic soils with stage I to II development. Corresponds to unit Q3 of Dickey and others (1980). Maximum exposed thickness up to $3 \mathrm{~m}$

Qi Intermediate piedmont alluvium, undivided (late to middle Pleistocene)-Unconsolidated to weakly consolidated deposits of silt, sand, and gravel with rare boulders. Deposits form abandoned terraces and alluvial fan remnants on the piedmonts of the Black and Newberry Mountains. In the central part of the map, younger unit Qi deposits are confined to deeply incised valleys that commonly host unit Qy deposits. Older unit Qi variants are more widely distributed relative to active drainages and occupy abandoned channel tracts and fan swaths that are cut less deeply into older units. Sediments are poorly to moderately sorted and bedded, subangular to subrounded, and locally derived. Intermediate-age surfaces include relict alluvial fan and fan terraces that are isolated from active, constructional fluvial processes but do host local, typically dendritic drainage networks. Four subunits (Qi4, Qi3, Qi2, Qi1) of this unit are present in the map area

Q44 Unit 4 (late Pleistocene) - Sand, gravel, silt, and rare boulder deposits of inactive washes and alluvial fans draining the Black and Newberry Mountains. Deposits are mostly restricted to valleys of active piedmont drainages where they form terraces $<10 \mathrm{~m}$ above active channels. Sediments are poorly to moderately sorted and bedded, subangular to subrounded, and locally derived. Weak soil development with moderate $\mathrm{Bw}$ horizons and stage I to II soil carbonate horizon development. This unit is inset to Qi3 and older units in most locations and has expression as small fan remnants at the mouths of some large washes where they enter Lake Mohave. Moderate varnish on clasts. Moderate gravel lags to weak pavements particularly in swales. Depositional topography weakly to moderately muted; coarse bars and weakly to moderately paved swales are evident in the field. Deposits have stage I to II pedogenic carbonate morphology. Some deposit surfaces resemble those of Qi3 but are inset into them and unit Qch in middle to lower piedmont area. Unit is generally similar to Q2b and older parts of Q3 of Dickey and others (1980) and unit Qs3 of Howard and others (1999). Maximum exposed thickness approximately $10 \mathrm{~m}$

Qi3 Unit 3 (late Pleistocene) - Weakly consolidated to unconsolidated, poorly sorted, poorly bedded, subangular to subrounded locally derived sand, pebbles, and cobbles and rare boulders. Thickness as much as at least $10 \mathrm{~m}$, but typically variable and thinner. Relict terrace surface of unit in relatively broad, deeply 
incised valleys cuts into unit Tfb and stands 6-8 $\mathrm{m}$ above active channels. Distal parts of unit Qi3 remnants are commonly only a few meters thick and truncate underlying unit Qch deposits, although interbedded unit Qch is also present in several places. Unit may contain rare pebbles from older Colorado River deposits. Division of unit Qi3 into two subunits can be made based on observable relations to the Chemehuevi Formation in some areas of the river corridor (for example, House and others, 2018; Gootee and others, 2016), but these relations are not well expressed in this map area. In several places unit Qi3 fans extend over and bevel the highest deposits of the Chemehuevi Formation (unit Qch, for example, figs. 12A, 13). Deposit surfaces are fully smooth with well-developed, darkly varnished pavements. Tight desert pavement development is common. Unit Qi3 deposits host moderately developed soils with stage II to mostly stage III pedogenic carbonate morphology. It is notable that carbonate horizon development on unit Qi3 (and all older surfaces) in the Arizona part of the map area is stronger than on equivalent deposits in most areas to the south in the river corridor. Unit Qi3 is likely to be equivalent to parts of the intermediate alluvium (units Q2a, Q2b) of Dickey and others (1980) and (or) unit 2 (Qs2) of Wilshire and Reneau (1992) and Howard and others (1999)

Unit 2 (late to middle? Pleistocene) - Relatively high standing fan and fan-terrace remnants composed of weakly consolidated to unconsolidated, poorly sorted, poorly bedded, subangular to subrounded sand, gravel, and silt and rare boulders of local origin. Surfaces are moderately dissected and have limited area of pristine fan surfaces relative to unit Qi3. Where preserved, unit Qi2 surfaces are relatively flat with rough pavements that have moderately to strongly weathered protruding clasts, abundant overturned pebbles and cobbles, and some carbonate detritus. The most extensive remnants of unit Qi2 are associated with abandoned fans and flow paths amidst high-standing remnants of older piedmont and river deposits. Relict surfaces stand $\sim 18 \mathrm{~m}$ above active washes. Predates unit Qch and may bear distinct erosional scarps at levels similar to the highest unit Qch remnants. Erosional remnants of this unit are mostly buried under units Qch and Qi3 in lower piedmont areas. It is possible that older alluvial units with very similar composition are included in the mapping of buried parts of unit Qi2. Well-preserved surfaces in the map area are underlain by soils with moderate to strong stage III pedogenic carbonate. Maximum observed thickness approximately $12 \mathrm{~m}$. Correlative to unit Q2a of Dickey and others (1980) and tentatively to older parts of unit Qs2a of Wilshire and Reneau (1992) and Howard and others (1999)

Unit 1 (middle Pleistocene) - High-standing fan and fan-terrace remnants composed of weakly consolidated to unconsolidated, poorly sorted, poorly bedded, subangular to subrounded sand, gravel, and silt and rare boulders of local origin. Surfaces are somewhat rounded and have limited extent of relatively narrow and smooth surface remnants. Where present, these remnants have rough, irregular pavements that contain moderately to strongly weathered protruding cobble clasts and rock fragments, overturned clasts, and carbonate detritus. Deposits have soils with strong stage III to IV pedogenic carbonate horizons. Unit recognized when in inset relations with older and younger units, but otherwise likely included in areas mapped as unit QTa. Correlative to unit Q1b of Dickey and others (1980) and tentatively to older parts of unit Qs2a of Wilshire and Reneau (1992) and Howard and others (1999). Maximum thickness likely less than $8 \mathrm{~m}$

Qo Older piedmont alluvium (middle to early? Pleistocene) - Old alluvial fan remnants composed of locally derived gravel and sand from the Black and Newberry Mountains. Capped with petrocalcic soil horizon with moderate to strong pedogenic carbonate development between stages IV and V (unit Qbk3). Where alluvium is absent or particularly thin, only the petrocalcic cap is mapped. Correlative to older parts of unit Q1b and possibly to younger parts of unit QT1a of Dickey and others (1980). Maximum exposed thickness approximately $10 \mathrm{~m}$

QTa Oldest piedmont alluvium, undivided (early Pleistocene to late Pliocene?) - Sparse, erosional remnants of ancient alluvial fan deposits. May include parts of Black Mountain fanglomerate units (Tfb, Tfb3, Tfb2, Tfb1) and unit Qo. Associated with degraded and rounded ridges with surface litter composed of moderately to deeply weathered gravel clasts and abundant disaggregated fragments and chunks of petrocalcic soil. This unit also includes old to ancient alluvium of uncertain stratigraphic affinity. Correlative to QT1a of Dickey and others (1980). Thickness likely ranges from 10 to $>100 \mathrm{~m}$

\section{Pedogenic Units}

QTbk Soil carbonate, undivided (Pleistocene and Pliocene)-Massive and extremely strongly developed petrocalcic soil and pedogenic calcrete remnants developed in ancient alluvial deposits and landforms that postdate the $4 \mathrm{Ma}$ Bullhead Alluvium (fig. 14). These massive calcrete mesas include Bkm- to Bkqm-type soils and have complex polygenetic pedogenic carbonate horizons as thick as $3.5 \mathrm{~m}$ that have reached developmental stages of IV to VI (terminology of Machette, 1985). These units have been mapped as discrete entities following the convention of Williams (1996) for comparable features in the 
Mormon Mesa area near Mesquite, Nevada. In our map area, the massive soils cap is formed in mostly piedmont alluvium associated with ancient fans emanating from large drainages like Tyro, Granite/ Portland, and Lost Cabin Washes. Some sites near Lake Mohave contain notable admixtures of Colorado River sediment and, therefore, possibly include ancient fluvial terrace remnants. The soil-hosting layers are commonly composed of strongly to very strongly consolidated layers of tributary gravel and (locally) minor to moderate mixtures of Colorado River sediment cemented by calcium carbonate. The soil horizons are chiefly composed of pedogenic calcium carbonate with minor amounts of silica, including the clay minerals palygorskite and sepialite (Brock, 2007). Surfaces on top of these massive soil horizons are mostly exhumed and commonly host variable lag of coarse, darkly varnished gravel and large numbers of fragmented, light-gray to white blocks of brecciated carbonate soil litter. The largest carbonate pendants on disaggregated surface clasts and evident in exposures of petrocalcic horizons exceed $5 \mathrm{~cm}$ in length and diameter.

Three levels of massive, strongly consolidated pedogenic calcrete remnants are traceable on correlative fan surfaces from the center of Cottonwood Valley to the west face of the Black Mountains just outside of the quadrangle. Where the soils are formed in deposits rich with Colorado River sediments, they show evidence for pressure dissolution of silica-rich pea-gravel clasts. These pedogenic-mesa features were first described as the "tablelands of the lower Colorado River" by J.S. Newberry, geologist of the 1857-58 Ives expedition (Newberry, 1861). He interpreted the soils as freshwater limestones and remarked on the apparent purity of carbonate in some outcrops. Each of these levels corresponds to a different generation of piedmont alluvial unit and forms an inset sequence of ancient landforms that track progressive incision into the Bullhead Alluvium and other underlying units from the Pliocene to the early Pleistocene. Areas mapped as unit QTbk may also include a few meters of the soil-hosting gravel deposit, or they may just be a soil cap on an erosional landform. The gravels are mapped separately only where their thickness or outcrop pattern allow it

Qbk3 Unit 3 (middle? Pleistocene) - Strongly consolidated petrocalcic soil-horizon remnant associated with unit Qo; stage IV to V Bk horizons are present. Maximum thickness approximately $1.5 \mathrm{~m}$

Qbk2 Unit 2 (middle to early? Pleistocene) -Pedogenic calcrete cap that has formed in second oldest piedmont alluvial unit that postdates the Bullhead Alluvium. Stage V to VI Bk horizons are present. Maximum thickness approximately $2 \mathrm{~m}$

QTbk1 Unit 1 (early Pleistocene to Pliocene)—Pedogenic calcrete cap that has formed in oldest piedmont alluvial unit that bevels (postdates) the Bullhead Alluvium, unit Tfb3. Stage VI Bkm to Bkqm carbonate horizons are present, some with remarkably clean laminar horizons. Newberry (1861) visited one of these sites in 1858-59 (Pyramid mesa at NE $1 / 4 \mathrm{NW}^{1} / 4$ sec 6, T. 22 N., R. 21 W.; lat $35.3302^{\circ}$ N., long $114.5656^{\circ} \mathrm{W}$.) and interpreted it as a clean freshwater limestone atop Colorado River sediments. We concluded that it is an extremely strongly developed carbonate soil that was formed in a possible ancient fluvial terrace of the Colorado River or cleanly exhumed strata of the Bullhead Alluvium. Maximum thickness approximately $3 \mathrm{~m}$

\section{Older Fanglomerate and Channel Deposits}

Tfn Fanglomerate of Newberry Mountains (Pliocene and Miocene)-Alluvial fan and wash deposits composed predominantly of light-greenish-gray to light-gray plutonic rocks and a subordinate component of darker clasts derived from intermediate and mafic dikes and gneiss exposed in the Newberry Mountains (see fig. 8). Much of this unit is light in tone and contrasts markedly with coeval and younger fanglomerate deposits derived from rocks in the Black Mountains, Arizona (units Tfb, Tfb3, Tfb2, Tfb1; fig. 10). The unit has been differentiated from Black Mountains-derived fanglomerates on the map to approximate boundaries of the pre-Colorado River axial valley and the approximate trace of the early Bullhead Alluvium valley axis (for example, figs. 1,2). The distribution of unit Tfn clearly indicates that ancient tributary fans sourced from the Newberry Mountains extended more than $1 \mathrm{~km}$ eastward beyond the modern valley axis (fig. 2A). Interbedded units Tfn and Tfb1, mapped as unit Tfco, mark the axis of the valley prior to the arrival of the Colorado River. Maximum observed thickness is approximately $90 \mathrm{~m}$ ately bedded, and variably to strongly consolidated deposits of locally derived sand and gravel dominantly from the Black Mountains. Unit is lithologically distinct from Tfn because of substantially larger component of dark-brown, gray, and purplish-gray volcanic clasts. This unit is further subdivided, based on age relative to Bouse Formation and Bullhead Alluvium deposition. Subunit Tfb1 denotes pre-Bouse Formation deposition; subunit Tfb2 denotes post-Bouse Formation and often syn-Bullhead Alluvium deposition; and subunit Tfb3 is reserved for a later post-Bullhead Alluvium unit that is commonly 
exposed below major calcic soil horizons and pedogenic calcrete horizons (unit QTbk) graded to levels below the highest extant deposits of Bullhead Alluvium. Maximum observed thickness approximately $50 \mathrm{~m}$

Tfb3 Unit 3 (Pliocene) - Fanglomerate unit that cuts the Bullhead Alluvium and hosts an extremely strong carbonate soil cap (multiple meters thick and stage V to VI carbonate development). Unit is capped with extremely strongly developed petrocalcic soil remnants of QTbk1 or Qbk2 (for example, fig. 3). This group of alluvial fan deposits was graded to a series of high-standing post-Bullhead levels of the Colorado River for which little other field evidence remains. Tentatively correlated to alluvial fan strata to the south near Bullhead City, Arizona, that contain the 3.3-Ma Nomlaki Tuff Member of the Tehama Formation (House and others 2005b, 2008b; Pearthree and House, 2014). Maximum observed thickness approximately $20 \mathrm{~m}$. (Note that some co-authors would prefer this unit to be included in unit QTa)

Tfb2 Unit 2 (Pliocene) - Black Mountains-derived fanglomerate unit that postdates the climactic aggradation of the Bouse Formation and is coeval with deep incision into the Bouse Formation and subsequent thick aggradation associated with the deposition of the Bullhead Alluvium. Exposures in Lost Cabin Wash indicate that lower parts of this unit track deep incision into the Bouse Formation and contain relatively large amounts of reworked chunks and clasts of Bouse Formation deposits. Thus, the lower part of the unit may somewhat predate aggradation of the Bullhead Alluvium. Maximum thickness estimated $>100 \mathrm{~m}$

Tfb1 Unit 1 (Pliocene and Miocene) - Moderately to strongly indurated cobble-rich fanglomerate deposits of the Black Mountains and (subordinately) deformed fanglomerate deposits of the Black or Newberry Mountains where lithologic provenance is ambiguous. Poorly bedded overall, but some intervals of relatively fine, cross-bedded gravels are present. This unit spans a considerable amount of time and locally includes strongly deformed strata that significantly predate the deposition of the Bouse Formation and the beds of Lost Cabin Wash. See discussion of preliminary structural analysis in Evidence of Faulting and Deformation. Possibly contains lithologies associated with syntectonic denudation. Maximum thickness at least $120 \mathrm{~m}$

Tfcy Young paleochannel-fill conglomerate (early Pliocene) - Well-sorted, subangular to subrounded fluvial boulders, cobbles, and sand that occupy a string of discontinuous paleochannel forms on the lower piedmont of the Newberry Mountains in the northwest corner of the map area (for example, fig. 11). Cobble and boulder clasts in this deposit are predominantly locally derived, but outcrops near the shore of Lake Mohave contain exotic sand and pebbles to small cobbles typical of the Colorado River. On the Newberry Mountain piedmont to the north and west of this map area, discontinuous outcrops of these channel deposits can be traced for several miles. It is not clear whether they are the same channel or a series of channels. The channel forms are transverse to the depositional fabric of underlying fanglomerate deposits (some of which are tilted) and the channel fills include cross-bedded subrounded local sand and gravels. An outcrop in lower White Rock Wash (lat $35.3287^{\circ}$ N., long $114.6164^{\circ}$ W.) is cemented by sparry calcite and occupies a channel form cut into volcanic bedrock (fig. 11A). The White Rock Wash paleochannel in that figure does not contain exotic clasts, but nearer the lake shore between White Rock and Seven-Eleven Coves, the unit is interbedded with the Bullhead Alluvium (unit Tcb), indicating a coeval relation (fig. 11C). The paleochannel gravels cut across the depositional fabric of underlying fan deposits and the present erosional topographic fabric of ancient landforms. These paleochannel deposits are likely coeval with the older parts of units Tcb and Tfb2. Maximum thickness about $18 \mathrm{~m}$

\section{ANCESTRAL COLORADO RIVER DEPOSITS}

Qcr Riverside alluvium (late Pleistocene) - Unconsolidated to weakly consolidated sand and gravel deposits of the Colorado River. Unit includes a discontinuous suite of thin river terraces and gravel lags. Thickness rarely exceeds $3 \mathrm{~m}$. Calcified wood fragments and rhizoliths are abundant locally, though are somewhat rare overall. The extent of fluvial terraces in this map is limited. Many remnants are small and partly buried by mixed colluvium (unit Qtc) shed from slopes of high-standing landforms. Terrace sediments have stage II to III carbonate soil horizons. Well-preserved surfaces support moderately to very well developed pavements of moderately to very darkly varnished, well-rounded Colorado River-derived pebbles and cobbles. Some unit Qcr areas may include older and exhumed river-lain strata and may host only thin layers of reworked gravels. All of the Riverside terrace surfaces in this map are inset below and postdate the aggradation of the Chemehuevi Formation (unit Qch). Pre-reservoir aerial photographs and maps indicate that at least one additional flat and varnished terrace surface is present below the surface of Lake Mohave in the map area. Unit is equivalent to young deposits grouped in unit QTr in Dickey and others (1980); unit Qrd of Howard and others (1999); units Qc2 and Qc3 of Pearthree and House (2005); and unit Qcts of Gootee and others (2016), House and others (2008a), House and Faulds (2009), and Spencer and others (2015). Maximum thickness $<5 \mathrm{~m}$ 
Qch Chemehuevi Formation (late Pleistocene) - Colorado River mud, sand, and gravel (Malmon and others, 2011). Deposits typically form a conspicuous stratigraphic couplet of a relatively loose sand-dominated facies overlying a more competent bluff- and badland-forming mud-dominated facies, commonly along a mild erosional unconformity (fig. 12C). A gravel facies is rarely present in the formation and was not observed in this map area. Most exposures in this map area are of the mud-dominated facies. These deposits are typically beveled and covered by deposits of piedmont unit Qi3 that host moderately to strongly developed stage III carbonate horizons. Exposed deposits unit Qch rarely contain surface soils. It is common to see the base of Qch buttressed against or filling erosional topography and sitting atop paleosols (fig. 4A). Other occurrences include degraded remnants that onlap west-facing slopes below high-standing calcrete-capped mesas underlain by Bullhead Alluvium and Black Mountain fanglomerate units (Tcb, Tcbm, Tcbs, Tcbb, Tcb/Tfn, Tcb/Tfb and Tfb, Tfb3, Tfb2, Tfb1). In these areas, the unit is covered with a 0 - to 1 -m-thick mantle of colluvium and loose talus (unit Qtc) from those higher surfaces and deposits. Locally, the cover is stripped, and the mud facies is exposed and forms distinctive badland topography. At lat $35.3128^{\circ} \mathrm{N}$., long $114.5846^{\circ} \mathrm{W}$., the $\sim 70$-ka Monkey Rock tephra bed of Malmon and others (2011) was identified at the base of the unit near Desert Cove (fig. 12B,C). In several areas beyond this map, Lundstrom and others (2008) reported luminescence ages from the mud facies of the Chemehuevi Formation ranging from 80 to $40 \mathrm{ka}$. Calcified wood fragments and rhizoliths are commonly found in this unit, but silicified wood is not present. Maximum observed thickness $40 \mathrm{~m}$

Older Colorado River deposits (Pleistocene) - This unit includes deposits of mud and fine sand that are not clearly stratigraphically linked to units Tcb, Qch, or younger units. Limited exposures, but they have been found underlying unit Qi1. Maximum observed thickness about $6 \mathrm{~m}$

Tcb Bullhead Alluvium, undivided (Pliocene) — Thick and voluminous deposit of the early Colorado River composed of well-rounded to subrounded gravel, sand, and minor mud. The type locality of the Bullhead Alluvium is located near Tyro Wash in the Spirit Mountain SE 7.5' quadrangle (figs. 1B, 7A, 5B,D; Howard and others, 2015). Unit ranges in age from approximately 4.5 to 3.5 Ma (Howard and others, 2015). Deposits range from unconsolidated to strongly consolidated, depending on the relative proportions of fluvial sand and cementation. Sand-dominated sections typically are least consolidated and typically show elaborate cross-stratification (figs. $7 B, D$ ). Sandy intervals are typically gray to greenish gray in low-lying exposures and become more buff to tan higher in the section. This probably reflects a progressively more mixed and diverse sand fraction higher in the section as locally derived materials are conspicuously abundant in many exposures in the map area. Gravel intervals are dominated by pebbles and cobbles and commonly show planar bedding and trough cross-stratification (figs. 7C, 5D).

The gravel fraction of the lower parts of Bullhead Alluvium has a characteristic relation between clast provenance and sediment caliber (House and others, 2005b). The coarsest gravel (large cobbles to small boulders) is dominated by clasts derived from local fanglomerates (for example, fig. 6); medium gravel sizes (large pebbles to medium cobbles) are characterized by a mix of far-traveled, well-rounded clasts and subangular to subrounded clasts from local sources; and the finest gravel (for example, pea gravel) is dominated by far-traveled clasts. In the finest gravel, chert-clast-rich pea gravels are predominant. The Bullhead Alluvium is commonly interbedded with coarse fanglomerate deposits along its lateral margins and the highest extant deposits are commonly lenticular beds of Colorado River sediment in sequences of mostly fanglomerate deposits (fig. 9).

Boulder and coarse cobble conglomerate (unit Tcbb, described below) is common where the local base of the unit is exposed. The sand fraction of the lower parts of the Bullhead Alluvium in this map area has a substantial proportion of locally derived sediment, but it is dominated by sand from distant sources based on detrital zircon data (Kimbrough and others, 2015). Well-exposed sequences as thick as $50 \mathrm{~m}$ and composed of medium to thick tabular beds of strongly imbricated, commonly trough-crossstratified pebble and cobble gravel are common in the southern part of the quadrangle, centered on the type area near lower Tyro Wash (figs. $7 A, C, D$ ). Sets of imbricated gravel beds are interspersed with thick and amalgamated beds of cross-bedded medium to coarse sand, with minor lenses of mud. Total thickness of the unit in the map area is unknown, but it can be seen to extend at least several meters below the surface of Lake Mohave. Petrified wood fragments ranging in size from twigs to large logs and bark slabs have been observed at several sites in this map area. Much of the wood is distinctively pristine and shows little evidence of reworking following petrification. Some subrounded fragments of petrified wood in the unit were likely water worn prior to burial and petrification. The wood is commonly associated with strata of oxidized sand. At one location in the quadrangle near Katherine Powerline Cove, petrified and partially to unpetrified wood (lignite?) is found within diffuse zones of oxidation (fig. 7C). Deposits of unit Tcb are mostly undeformed but are mildly deformed locally. A key exposure near Chili Pepper Cove shows unit Tcb strata dipping $6^{\circ} \mathrm{NW}$., where they overlie unit Tfn dipping $30^{\circ} \mathrm{WSW}$. 
along an angular unconformity. Deformation in the Tyro Wash area was first described and depicted by Longwell (1963, p. E12). Maximum observed thickness about $200 \mathrm{~m}$

Tcbm Mud (Pliocene) - Reddish-brown to yellowish-brown fluvial clay and silt deposits. Flat lying, thin to medium bedded. Only divided out of unit Tcb in two locations on the map where relatively thick deposits crop out. This is a rare facies. Maximum observed thickness $<5 \mathrm{~m}$

Tcbs Sand (Pliocene) - Relatively thick, rare (in this map area) outcrops of fine-grained Colorado River-derived sand. Only divided out of unit Tcb where relatively thick deposits crop out conspicuously. Bullhead Alluvium sand and gravel are complexly interbedded in most outcrops in this map area. Maximum observed thickness $>8 \mathrm{~m}$ near Chili Pepper Cove (lat $35.2987^{\circ} \mathrm{N}$., long $114.5877^{\circ} \mathrm{W}$.)

Tcbb Boulder and cobble conglomerate (Pliocene) - Deposits of coarse conglomerate composed of clasts ranging from pebbles to rare large boulders deposited by the Colorado River. Deposits are strongly to poorly consolidated. Cobbles are the predominant clast type and are commonly far-traveled lithologies. Small and medium boulders of locally derived lithologies are the hallmark of this facies (fig. 8). This facies is common above erosive contacts with older fanglomerate or, less commonly, bedrock (fig. 10). A notable, coarse-cobble-dominated variant of this unit fills a paleochannel in Paleoproterozoic megacrystic granite near the shore of Lake Mohave between Chili Pepper and Desert Coves. The boulder fraction of this subunit is mostly derived from reworking of local fanglomerates by floods in the ancestral river. The Bullhead Alluvium channel complex crosscuts the axis of the Lost Cabin Wash paleovalley irregularly (fig. 15C) and eroded redistributed diagnostic fanglomerate from Newberry Mountains and Black Mountains alluvial fans. Consequently, compositional characteristics of this subunit vary over relatively short distances downvalley. An exposure in one deeply incised wash may contain a cargo of boulders derived from Newberry Mountain-sourced fanglomerate, whereas nearby exposures may contain predominantly reworked volcanic rocks from Black Mountains-sourced fanglomerate. Unit is quite similar to unit QTcb of House and others (2018) and unit Trbb of Howard and others (2013) except that it has an unambiguous affiliation to the Bullhead Alluvium. Maximum observed thickness $<6 \mathrm{~m}$

$\mathrm{Tcb} / \mathrm{Tfn}$ Interbedded with fanglomerate of Newberry Mountains (Pliocene) - Elongate lenses and relatively thick wedges of poorly to moderately sorted Newberry Mountains-derived gravel interbedded with well-sorted fluvial gravel and sand of the Bullhead Alluvium. Exposures north of Tyro Wash, in particular, show complex interbedded relations among thick wedges and lenses of coarse fanglomerate and Colorado River deposits. Interbedded unit Tfn fanglomerates are roughly coeval with unit Tfb2 but are somewhat to significantly older than underlying and commonly tilted unit Tfn deposits that are not interbedded with unit Tcb. Maximum observed thickness about $40 \mathrm{~m}$

$\mathrm{Tcb} / \mathrm{Tfb}$ Interbedded with fanglomerate of Black Mountains (Pliocene) - Complex sequence of interbedded, poorly to moderately sorted, locally derived gravel and well-sorted Colorado River fluvial sand. The boundaries of this unit are diffuse and hard to trace. The abundance of Colorado River sand and gravel deposits decreases sharply with lateral distance from the paleochannel system. At the farthest reaches, they are predominantly elongate lenticular beds in sections dominated by locally derived gravel deposits (fig. 9). The boundaries of this unit are complex and difficult to map with confidence, so it is delineated mostly with gradational contacts. Some contacts are estimated based on elevation contours in areas where outcrops have not been identified but could plausibly exist. Gradational contact placement is also supported by remote-sensing data that has been processed to highlight Colorado River sands (for example, Howard and others, 2008). The interbedded fanglomerates correspond to unit Tfb2, and their shared boundary is also mapped as gradational. Maximum observed thickness about $50 \mathrm{~m}$

Tbo

Bouse Formation, undivided (early Pliocene) - Well-sorted, well-bedded, fine-grained sand, mud, and marl. Underlain at many sites by distinctly oxidized zone in older units and, commonly, in thin beds of nearshore deposits of sand and gravel (unit Tbogg). The Bouse Formation is divided into two facies above the oxidized shoreline sediments: a basal carbonate (unit Tbocm) composed primarily of marl with minor travertine (tufa), overlain by a siliciclastic facies (unit Tbos) with interlayered beds of greenish-gray mud and orangish-pink quartz-rich sand (fig. $5 D$ ). In the highest outcrops in this quadrangle, unit Tbocm overlies relatively thin beds of indurated, calcareous, and cross-bedded sands. In these outcrops, the basal sands and the carbonate sediments exhibit intricate drapes that conform to irregular topography in underlying strata. Areas mapped as undivided Bouse Formation include thin remnants of multiple facies in single exposures. Exceptions include an area north of Lost Cabin Wash where tributary fan-delta deposits of medium-grained calcarenite are seen to bevel underlying bedded sediments of the siliciclastic facies. These sediments indicate deposition into a receding body of water and represent offlapping facies of the Bouse Formation. Gootee and others (2016) mapped a similar but more extensive unit near Cibola, Arizona. The maximum age of the Bouse Formation is constrained to $<5.24$ Ma by dating of a 5.37 Ma tephra layer and magnetostratigraphic data from the beds of Lost Cabin Wash in this 
map area (Crow and others, 2018, 2019a; Schwing, 2019). Farther south in the river corridor, the 4.8-5.0 Ma Lawlor Tuff is interbedded with Bouse Formation carbonate (Sarna-Wojcicki and others, 2011; Spencer and others, 2013; Harvey, 2014; Miller and Reynolds, 2014)

Tbos Mud and sand (early Pliocene) - Moderately to very well sorted and interbedded fine sand, silt, and clay, deposited in a delta of the nascent Colorado River. Includes sequences of laminated mudstones interbedded with planar laminated to thinly bedded fine- to medium-grained, rounded, quartz-rich sand. Muds are gypsiferous in places and alternate from light greenish gray to grayish orange pink. Sand beds are pink to pinkish gray and have thin oxidized laminae that are reddish yellow. Sand has abundant rounded quartz grains that range from translucent to light pink. Detrital zircon analysis of sands from exposures in Granite and Lost Cabin Washes clearly indicate Colorado River origin (Kimbrough and others, 2015). The unit commonly contains some amount of subangular to subrounded locally derived sands, as well. Paleontological analysis of two samples from this unit proved barren of microfossils. Maximum observed thickness about $30 \mathrm{~m}$

Tbocm Marl (early Pliocene) - White to gray, thinly bedded to massive marl (calcareous mudstone). Occurs as onlapping beds on bedrock and fanglomerate. Sometimes interbedded with calcarenite. Locally shows obvious draping over irregular topography formed on underlying surfaces. Map area contains only isolated deposits and thin beds of marl (for example, figs. 5B, 6). Maximum observed thickness about $3 \mathrm{~m}$

Tboct Tufa or travertine (early Pliocene) - Light-gray layered coatings of travertine on bedrock outcrops and between beds of fanglomerate. Typically, porous and deeply weathered with a rough, scabrous texture. Rarely more than $0.25 \mathrm{~m}$ thick. Found in close association with deposits of marl, calcareous sandstone, and wave-worked shoreline gravels in extremely small outcrops in the area of Lost Cabin Wash. Large outcrops in this map area are rare and extent of the largest outcrop is extremely small; extent is likely somewhat exaggerated on map. Maximum thickness $<0.5 \mathrm{~m}$

Tbogg Nearshore gravel (early Pliocene) - Moderately sorted to well-sorted, locally derived, subangular to subrounded coarse sand and pebble to cobble gravel, typically below the basal carbonate and calcareous sandstone (fig. 5A). Cross-stratification is common in good exposures. Rarely present as interbeds within the marl and travertine. Greenish-yellow to orange iron-oxide staining is common on gravel clasts and typically extends irregularly into underlying strata and underlying bedrock where present. Most commonly associated with clastic substrates (fanglomerate or colluvium) from which particles have been winnowed, milled, and sorted by wave action. Exposures are very limited in this map area, but localized thin beds of the unit are present in steep slopes above Lost Cabin Wash and several washes to the north. These exposures typically include thin to medium beds of reworked and rounded, locally derived cobbles with interbeds of calcareous sandstone and travertine. Maximum thickness $<2 \mathrm{~m}$

\section{PRE-RIVER BASIN-AXIS DEPOSITS}

Tlc Beds of Lost Cabin Wash (lower Pliocene to upper Miocene) - Weakly to strongly consolidated, light-reddish-brown to yellowish-brown sequence of well-bedded, gently dipping, and laterally continuous mudstone and sandstone composed of locally derived sediments (fig. 4). Gravels in the unit reflect predominantly clasts from the Black Mountains with subordinate clasts from the Newberry Mountains. Detrital zircon analyses indicate no affiliation with the Colorado River (Kimbrough and others, 2015). The unit is named for extensive exposures in Lost Cabin Wash, Arizona, where it forms vertical bluffs along nearly $2 \mathrm{~km}$ of the wash. Lost Cabin Wash strata are mostly flat lying to gently dipping (for example, $<1^{\circ}$ ). Roughly north-south-oriented lenticular gravel deposits are present throughout unit, but are most common in the lower $20 \mathrm{~m}$. The upper $10 \mathrm{~m}$ of unit contains paleosol indicators including desiccated horizons, iron-oxide leaching, abundant carbonate nodules, and vertical burrow structures. The lower 20 $\mathrm{m}$ of the unit contains abundant cross-bedded sands, common lenticular channels, and laterally continuous mud beds. Moderately dipping strata are present near the base of the sequence. The unit underlies the Bouse Formation along an unconformity that is particularly well exposed in Lost Cabin Wash and several unnamed washes to the north. Erosional channels associated with deposition of fanglomerate of Black Mountains cutting the top of the beds of Lost Cabin Wash contain mudballs and marl clasts reworked from the Bouse Formation. The beds of Lost Cabin Wash contain several fine-grained tephra layers, including the $5.59 \mathrm{Ma}$ tuff of Wolverine Creek identified in the informally named "odyssey wash" upstream of its mouth in South Haystack Cove (House and others, 2005b, 2008b). A younger tephra layer $\sim 36 \mathrm{~m}$ higher in the section was identified in "highwall wash" upstream of its mouth in Southern Basin Cove. That layer yielded an age of 5.37 Ma (fig. 4; Crow and others, 2018, 2019a). Magnetostratigraphic data from the unit indicate that the 5.37-Ma tephra is overlain by beds that contain a reversed to normal polarity transition correlated to the 5.24-Ma Thvera Subchron (Schwing, 2019). This shows that the upper beds of Lost Cabin Wash are younger than 5.24 Ma. Maximum observed thickness $>60 \mathrm{~m}$ 
Tfco Older paleochannel-fill conglomerate (upper and middle? Miocene) - Lithologically distinctive, flatlying, and strongly consolidated sequence of interbedded gravel and sand of the Newberry and Black Mountains. Unit grades upward into the beds of Lost Cabin Wash (unit TIc) and laterally into units Tfb1 and Tfn. Interpreted as part of a north-flowing axial valley fluvial system that conveyed sediments from lithologically distinct mountain watersheds on each side of Cottonwood Valley. Exposures of unit are limited and typically found in association with deeply incised, steep-sided slot canyons. The primary exposure is located east of Pack Rat and Mohave Crossing Coves in the area centered on lat $35.3367^{\circ}$ N., long $114.5666^{\circ}$ W. (fig. 3). Exposures here include an interbedded sequence of fine- and coarsegravel conglomerates with conspicuous affinities to either the lithologies of the Newberry (mostly light colored crystalline rocks) or the Black Mountains (dominated by variably colored volcanic rocks and dark crystalline rocks), or a mixture of both. Maximum thickness about $25 \mathrm{~m}$

Tnw Beds of Nellis Wash (upper and middle? Miocene) - Sequence of distinctive light-yellowish-brown, thin to thick beds of laminated claystone, siltstone, lithic sandstone, and minor gravel lenses. Unit is informally named for excellent exposures south of Nellis Wash in the adjacent Spirit Mountain NW 7.5' quadrangle. In map area, unit is primarily found in Cactus Cove (sec. 23, T. 23 N., R. 21 W.; lat $35.3707^{\circ}$ N., long $114.6040^{\circ}$ W.; fig. 2) along Arizona shore of Lake Mohave near the north edge of the map. At Cactus Cove, the unit is flat lying and offset approximately $6 \mathrm{~m}$ by a steep normal fault. It is overlain by mildly faulted unit Tfb fanglomerate at that location. Similar sediments that are likely Nellis Wash beds are present on the east flank of the informally named "Cottonwood butte" near Glory Cove near the north boundary of the map where the beds are dipping west. These beds may correlate in time and character to the Willow Beach beds of Amoroso (2010) and are coeval with part of the Muddy Creek Formation (Bohannon, 1984) and coeval basin-filling clastic and evaporite deposits in the Lake Mead region (Faulds, and others, 2016). Maximum thickness about $30 \mathrm{~m}$

\section{BEDROCK}

bdrk Bedrock, undivided (Miocene to Paleoproterozoic) - Bedrock has not been mapped but is known to include sequences of Miocene volcanic and sedimentary rocks, Miocene and Cretaceous(?) intrusive rocks, Proterozoic to Paleoproterozoic granite and gneiss, and mafic to intermediate dikes of various ages (for example, Faulds, 1995). There are a few locations along the Arizona shore of Lake Mohave where a cobble-dominated deposit of unit Tcbb overlies Paleoproterozoic megacrystic granite at several locations between Chili Pepper and Desert Coves (for example, fig. 10). A block of Proterozoic granitic gneiss is also found near the Arizona shoreline of Lake Mohave in the northwestern part of the map. The east edge of this block abuts moderately dipping beds of unit Tnw(?). Mylonitized bedrock was also noted near the intersection of cross sections $A-A^{\prime}$ and $B-B^{\prime}$. Maximum thickness unknown

\section{References Cited}

Amoroso, L., 2010, The Willow Beach beds-A pre-Colorado River axial basin deposit: Geological Society of America Abstracts with Programs, v. 42, no. 5, p. 75.

Beard, L.S., Anderson, R.E., Block, D.L., Bohannon, R.G., Brady, R.J., Castor, S.B., Duebendorfer, E.M., Faulds, J.E., Felger, T.J., Howard, K.A., Kuntz, M.A., and Williams, V.S., 2007, Preliminary geologic map of the Lake Mead 30'x60' quadrangle, Clark County, Nevada, and Mohave County, Arizona: U.S. Geological Survey Open-File Report 2007-1010, scale 1:100,000.

Bohannon, R.G., 1984, Nonmarine sedimentary rocks of Tertiary age in the Lake Mead region, southeastern Nevada and northwestern Arizona: U.S. Geological Survey Professional Paper 1259, $72 \mathrm{p}$.

Block, D., Gootee, B.F., House, P.K., and Pearthree, P.A., 2019, Geologic map of the Blythe 7.5' quadrangle, La Paz County, Arizona, and Riverside County, California: Arizona Geologi- cal Survey Digital Geologic Map 124 (DGM-124), 2 sheets and text.

Brock, A.L., 2007, Characterization of stage VI carbonate horizons, southern Nevada and northwestern Arizona: Las Vegas, University of Nevada, Ph.D. dissertation, 148 p.

Brock, A.L., and Buck, B.J., 2009, Polygenetic development of the Mormon Mesa, Nevada, petrocalcic horizons-Geomorphic and paleoenvironmental interpretations: Catena, v. 7, p. 65-75.

Buising, A.V., 1990, The Bouse Formation and bracketing units, southeastern California and western Arizona; implications for the evolution of the proto-Gulf of California and the lower Colorado River: Journal of Geophysical Research, v. 95, no. B12, p. 20,111-20,132.

Bull, W.B., 1991, Geomorphic response to climate change: England, Oxford University Press, $326 \mathrm{p}$.

Crow, R.S., Pearthree, P.A., House, P.K., Stelten, M., Heizler, M., Schwing, J.E., Champion, D., Howard, K.A., and Hillhouse, J., 2018, Geochronologic study of pre-Colorado River 
deposits in Cottonwood Valley, Arizona; implications for the timing of river integration: Geological Society of America Abstracts with Programs, v. 50, no. 5, ISSN 0016-7592, http://doi.org/10.1130/abs/2018RM-314086.

Crow, R.S., Schwing, J.E., Karlstrom, K.E., Heizler, M.T., Pearthree, P.A., House, P.K., Dulin, S.A., Stelten, M.E., and Crossey, L.J., 2019a, Redefining the age of the Colorado River: Geological Society of America Abstracts with Programs, v. 51, no. 5, ISSN 0016-7592, https://doi.org/10.1130/ abs/2019AM-339026.

Crow, R.S., Howard, K.A., Beard, L.S., Pearthree, P.A., House, P.K., Karlstrom, K.E., Peters, L., McIntosh, W., Cassidy, C., Felger, T.J., and Block, D., 2019b, Insights into post-Miocene uplift of the western margin of the Colorado Plateau from the stratigraphic record of the lower Colorado River: Geosphere, v. 15, p. 1-20, https://doi.org/10.1130/GES02020.1.

Dickey, D.D., Carr, W.J., and Bull, W.B., 1980, Geologic map of the Parker NW, Parker, and parts of the Whipple Mountains SW and Whipple Wash quadrangles, California and Arizona: U.S. Geological Survey Miscellaneous Investigations Series Map I-1124, scale 1:24,000.

Faulds, J.E., 1995, Geologic map of the Mount Davis quadrangle, Nevada and Arizona: Nevada Bureau of Mines and Geology, Map 105, scale 1:24,000.

Faulds, J.E., Feuerbach, D.L., Miller, C.F., and Smith, E.I., 2001, Cenozoic evolution of the northern Colorado River extensional corridor, southern Nevada and northwest Arizona: Pacific Section of the American Association of Petroleum Geologists, Publication GB 78 (also Utah Geological Association Publication 30), p. 239-272.

Faulds, J.E., House, P.K., Pearthree, P.A., Bell, J.W., and Ramelli, A.R., 2004, Preliminary geologic map of the Davis Dam quadrangle and eastern part of the Bridge Canyon quadrangle, Clark County, Nevada, and Mohave County, Arizona: Nevada Bureau of Mines and Geology, Open-File Report 2003-05, scale 1:24,000.

Faulds, J.E., House, P.K., Shevenell, L., and Ramelli, A, 2000, Geology and natural hazard assessment of the Laughlin area, Clark County, Nevada: Nevada Bureau of Mines and Geology, Open-File Report 2000-6.

Faulds, J.E., Schreiber, B.C., Langenheim, V.E., Hinz, N.H., Shaw, T.H., Heizler, M.T., Perkins, M.E., El Tabakh, M., and Kunk, M.J., 2016, Paleogeographic implications of late Miocene lacustrine and nonmarine evaporite deposits in the Lake Mead region-Immediate precursors to the Colorado River: Geosphere, v. 12, no. 3, p. 1-47, https://doi.org/10.1130/ GES01143.1.

Gootee, B.F., Pearthree, P.A., House, P.K., Youberg, A., Spencer, J.E., and O'Connell, B., 2016, Geologic map and report of the Cibola area, La Paz County, Arizona, and Imperial County, California: Arizona Geological Survey Digital Geologic Map DGM-112, 1 map plate, scale 1:24,000, 21 .

Harvey, J., 2014, Zircon age and oxygen isotopic correlations between Bouse Formation tephra and the Lawlor Tuff: Geosphere, v. 10, no. 2, p. 221-232.

House, P.K., Brock, A.L., and Pearthree, P.A., 2005a, Preliminary geologic map of the late Cenozoic alluvium in the west half of the Spirit Mountain SE quadrangle, Arizona and Nevada: Nevada Bureau of Mines and Geology Open-File Report 2005-08 (superseded by Open-File Report 08-3), scale $1: 24,000$.

House, P.K., Brock, A.L., and Pearthree, P.A., 2008a, Preliminary geologic map of late Cenozoic deposits in the Spirit Mountain SE quadrangle, Clark County, Nevada, and Mohave County, Arizona: Nevada Bureau of Mines and Geology Open-File Report 08-3, scale 1:24,000.

House, P.K., Buck, B.J., and Ramelli, A.R., 2010, Geologic assessment of piedmont and playa flood hazards in the Ivanpah Valley area, Clark County, Nevada: Nevada Bureau of Mines and Geology Report 53, https://pubs.nbmg.unr.edu/ Geol-flood-hazard-Ivanpah-Valle-p/m158.htm.

House, P.K., and Faulds, J.E., 2009, Preliminary geologic map of the Spirit Mountain NW quadrangle, Clark County, Nevada, and Mohave County, Arizona: Nevada Bureau of Mines and Geology Open-File Report 2009-06, scale 1:24,000.

House, P.K., John, B.E., Malmon, D.V., Block, D., Beard, L.S., Felger, T.J., Crow, R.S., Schwing, J.E., and Cassidy, C.E., 2018, Geologic map of the Castle Rock 7.5' quadrangle, Arizona and California: U.S. Geological Survey Scientific Investigations Map 3411, scale 1:24,000, pamphlet 15 p., https:// doi.org/10.3133/sim3411.

House, P.K., Pearthree, P.A., Howard, K.A., Bell, J.W., Perkins, M.E., Faulds, J.E., and Brock, A.L., 2005b, Birth of the lower Colorado River-Stratigraphic and geomorphic evidence for its inception near the conjunction of Nevada, Arizona, and California, in Pederson, J., and Dehler, C.M., eds., Interior western United States: Geological Society of America Field Guide 6, p. 357-387.

House, P.K., Pearthree, P.A., and Perkins, M.D., 2008b, Stratigraphic evidence for the role of lake-spillover in the birth of the lower Colorado River in southern Nevada and western Arizona, in Reheis, M.C., Hershler, R., and Miller, D.M., eds., Late Cenozoic drainage history of the southwestern Great Basin and lower Colorado River region; geologic and biotic perspectives: Geological Society of America Special Paper 439, p. 333-351.

Howard, K.A., House, P.K., Dorsey, R.J., and Pearthree, P.A., 2015, River evolution and tectonic implications of a major Pliocene aggradation on the lower Colorado River-The Bullhead Alluvium: Geosphere, v. 1, no. 1, p. 1-30.

Howard, K.A., House, P.K., John, B.E., Crow, R.S., and Pearthree, P.A., 2019, A river is born-Highlights of the geologic evolution of the lower Colorado River extensional corridor and its river; A field guide honoring the life and legacy of Warren Hamilton, in Pearthree, P.A., ed., Geologic excursions in southwestern North America: Geological Society of America Field Guide 55, p. 61-113, https://doi. org/10.1130/2019.0055(03).

Howard, K.A., and John, B.E., 1987, Crustal extension along a rooted system of imbricate low-angle faults - Colorado River extensional corridor, California and Arizona, in Coward, M.P., Dewey, J.F., and Hancock, P.L., eds., Continental extensional tectonics: Geological Society of London, Geological Society Special Publications, no. 28, p. 299-311. 
Howard, K.A., John, B.E., Nielson, J.E., Miller, J.M.G., and Wooden, J.L., 2013, Geologic map of the Topock 7.5' quadrangle, Arizona and California: U.S. Geological Survey, Scientific Investigations Map SIM-3236, scale 1:24,000.

Howard, K.A., Lundstrom, S.C., Malmon, D.V., and Hook, S.J., 2008, Age, distribution, and formation of paleovalleys of the lower Colorado River and their relation to aggradation and degradation, in Reheis, M.C., Hershler, R., and Miller, D.M., eds., Late Cenozoic drainage history of the southwestern Great Basin and lower Colorado River region; geologic and biotic perspectives: Geological Society of America Special Paper 439, p. 391-410.

Howard, K.A., Nielson, J.E., Wilshire, H.G., Nakata, J.K., Goodge, J.W., Reneau, S.L., John, B.E., and Hansen, V.L., 1999, Geologic map of the Mohave Mountains area, Mohave County, western Arizona: U.S. Geological Survey Miscellaneous Investigations Series Map I-2308, scale 1:48,000.

Kimbrough, D.L. Grove, M., Gehrels, G.E., Dorsey, R.J., Howard, K.A., Lovera, O., Aslan, A., House, P.K., and Pearthree, P.A., 2015, Detrital zircon U-Pb provenance of the Colorado River-A 5 m.y. record of incision into cover strata overlying the Colorado Plateau and adjacent regions: Geosphere, v. 11, no. 6, p. 1-30, https://doi.org/10.1130/GES00982.1.

Knott, J.R., Machette, M.N., Wan, E., Klinger, R.E., Liddicoat, J.C., Sarna-Wojcicki, A., Fleck, R.J., Deino, A.L., Geissman, J.W., Slate, J.L., Wahl, D.B., Wernicke, B.P., Wells, S.G., Tinsley, J.C., III, Hathaway, J.C., and Weamer, V.M., 2018, Late Neogene-Quaternary tephrochronology, stratigraphy, and paleoclimate of Death Valley, California, USA: Geological Society of American Bulletin, v. 130, no. 7-8, p. 1231-1255, https://doi.org/10.1130/B31690.1.

Knott, J.R., Machette, M.N., Klinger, R.E., Sarna-Wojcicki, A.M., Liddicoat, J.C., Tinsley, J.C., III, David, B.T., and Ebbs, V.M., 2008, Reconstructing late Pliocene to middle Pleistocene Death Valley lakes and river systems as a test of pupfish (Cyprinodontidae) dispersal hypotheses, in Reheis, M.C., Hershler, R., and Miller, D.M., eds., Late Cenozoic drainage history of the southwestern Great Basin and lower Colorado River region-Geologic and biotic perspectives: Geological Society of America Special Paper 439, p. 1-26, https://doi.org/10.1130/2008.2439(01).

Kreemer, C., Blewitt, G., and Hammond, W.C., 2010, Evidence for an active shear zone in southern Nevada linking the Wasatch Fault to the eastern California shear zone: Geology, v. 38, no. 5, p. 475-478.

Langenheim, V.E., Beard, L.S., and Faulds, J.E., 2010, Implications of geophysical analysis on basin geometry and fault offsets in the northern Colorado River extensional corridor and adjoining Lake Mead region, Nevada and Arizona, in Umhoefer, P.J., Beard, L.S., and Lamb, M.A., eds., Miocene tectonics of the Lake Mead region, central Basin and Range: Geological Society of America Special Paper 463, p. 39-59, https://doi.org/10.1130/2010.2463(03).

Lee, W.T., 1908, Geologic reconnaissance of a part of western Arizona: U.S. Geological Survey Bulletin 352, 96 p.

Longwell, C.R., 1963, Reconnaissance geology between Lake Mead and Davis Dam, Arizona-Nevada: U.S. Geological Survey Professional Paper 374-E, 51 p.
Lucchitta, I., 1972, Early history of the Colorado River in the Basin and Range Province: Geological Society of America Bulletin, v. 83, no. 7, p. 1933-1948.

Lundstrom, S.C., Mahan, S.A., Paces, J.B., Hudson, M.R., House, P.K., Malmon, D.V., Blair, J.L., and Howard, K.A., 2008, Late Pleistocene aggradation and degradation of the lower Colorado River-Perspectives from the Cottonwood area and other reconnaissance below Boulder Canyon: Geological Society of America Special Paper 439, p. 409-430.

Machette, M.N, 1985, Calcic soils of the southwestern United States, in Weide, D.L., ed., Soils and Quaternary geology of the southwestern United States: Geological Society of America Special Paper 203, p. 1-22.

Malmon, D.V., Howard, K.A., House, P.K., Lundstrom, S.C., Pearthree, P.A., Sarna-Wojcicki, A.M., Wan, E., and Wahl, D.B., 2011, Stratigraphy and depositional environments of the upper Pleistocene Chemehuevi Formation along the lower Colorado River: U.S. Geological Survey Professional Paper 1786, 95 p., https://pubs.usgs.gov/pp/1786/.

Metzger, D.G., 1968, The Bouse Formation (Pliocene) of the Parker-Blythe-Cibola area, Arizona and California: U.S. Geological Survey Professional Paper 600-D, p. 126-136.

Metzger, D.G., and Loeltz, O.J., 1973, Geohydrology of the Needles area, Arizona, California, and Nevada: U.S. Geological Survey Professional Paper 486-J, p. 1-54.

Metzger, D.G., Loeltz, O.J., and Irelan, B., 1973, Geohydrology of the Parker-Blythe-Cibola area, Arizona and California: U.S. Geological Survey Professional Paper 486-G, p. 1-130.

Miller, D.M., and Reynolds, R.E., 2014, Bouse Formation in the Bristol basin near Amboy, California: Geosphere, v. 10, no. 3, p. 462-475, https://doi.org/10.1130/GES00934.1.

Newberry, J.S., 1861, Geologic report, in Ives, J.C., Report upon the Colorado River of the West: U.S. 36th Congress, 1st Session, Senate and House Executive Document 90, pt. 3, $154 \mathrm{p}$.

Olmstead, F.H., Loeltz, O.J., and Irelan, B., 1973, Geohydrology of the Yuma Area, Arizona and California: U.S. Geological Survey Professional Paper, 486-H, 227 p., https://doi.org/10.3133/pp486H.

Pearthree, P.A., and House, P.K., 2005, Geologic map of the Davis Dam SE 7.5' quadrangle, Mohave County, Arizona, and Clark County, Nevada: Arizona Geological Survey Digital Geologic Map DGM-45, version 1.0, map scale 1:24,000.

Pearthree, P.A., Ferguson, C.A., Johnson, B.J., and Guynn, Jerome, 2009, Geologic map and report for the proposed state route 95 realignment corridor, Mohave County, Arizona: Arizona Geological Survey Digital Geologic Map DGM-65, version 1.0, map scale 1:24,000, 47 p. and 5 map sheets.

Pearthree, P.A., and House, P.K., 2014, Paleogeomorphology and evolution of the early Colorado River inferred from relationships in the Mohave and Cottonwood Valleys, Arizona, California, and Nevada: Geosphere, v. 10, no. 6, p. 1139-1160, https://doi.org/10.1130/GES00988.1.

Roskowski, J.A., Patchett, P.J., Spencer, J.E., Pearthree, P.A., Dettman, D.L., Faulds, J.E., and Reynolds, A.C., 2010, A late Miocene-early Pliocene chain of lakes fed by the Colorado River-Evidence from Sr, C, and O isotopes of the Bouse 
Formation and related units between Grand Canyon and the Gulf of California: Geological Society of America, Bulletin 122, v. 9-10, p. 1625-1636.

Sarna-Wojcicki, A.M., Deino, A.L., Fleck, R.J., Mclaughlin, R.J., Wagner, D., Wan, E., Wahl, D., Hillhouse, J.W., and Perkins, M.E., 2011, Age, composition, and areal distribution of the Pliocene Lawlor Tuff and three younger Pliocene tuffs, California and Nevada: Geosphere, v. 7, no. 3, p. 599-628, https://doi.org/10.1130/GES00609.1.

Schwing, J.E., 2019, Magnetostratigraphy of the pre-Colorado River integration Lost Cabin beds, Cottonwood Valley, Arizona: Norman, University of Oklahoma, M.S. thesis., 109 p. Spencer, J.E., Patchett, P.J., Pearthree, P.A., House, P.K., SarnaWojcicki, A.M., Wan, E., Roskowski, J.A., and Faulds, J.E., 2013, Review and analysis of the age and origin of the Pliocene Bouse Formation, lower Colorado River Valley, southwestern USA: Geosphere, v. 9, no. 3, p. 444-459, https://doi.org/10.1130/GES00896.1.
Spencer, J.E., Pearthree, P.A., House, P.K. and Reynolds, S.J., 2015, Geologic map of the Cross Roads 7.5' quadrangle and the southern part of the Gene Wash 7.5' quadrangle, La Paz County, Arizona, and San Bernardino County, California: Arizona Geological Survey Digital Geologic Map DGM-111, scale 1:24,000.

Spencer, J.E., Singleton, J.S., Strickland, E., Reynolds, S.J., Love, D., Foster, D.A., and Johnson, R., 2018, Geodynamics of Cenozoic extension along a transect across the Colorado River extensional corridor: Geosphere, v. 10, no. 6, p. 743-759, https://doi.org/10.1130/L1002.1.

Williams, V.S., 1996, Preliminary geologic map of the Mesquite quadrangle, Clark and Lincoln County, Nevada and Mohave County, Arizona: U.S. Geological Survey Open-File Report 96-676.

Wilshire, H.G., and Reneau, S.L., 1992, Geomorphic surfaces and underlying deposits of the Mohave Mountains piedmont, lower Colorado River, Arizona: Zeitschrift für Geomorphologie, v. 36, no. 2, p. 207-226. 